\title{
Persistent multi-decadal Greenland temperature fluctuation through the last millennium
}

\author{
Takuro Kobashi • Jeffrey P. Severinghaus • \\ Jean-Marc Barnola • Kenji Kawamura • \\ Tara Carter · Tosiyuki Nakaegawa
}

Received: 28 April 2008 / Accepted: 28 July 2009 / Published online: 3 October 2009

(C) The Author(s) 2009. This article is published with open access at Springerlink.com

\begin{abstract}
Future Greenland temperature evolution will affect melting of the ice sheet and associated global sea-level change. Therefore, understanding Greenland temperature variability and its relation to global trends is critical. Here, we reconstruct the last 1,000 years of central Greenland surface temperature from isotopes of $\mathrm{N}_{2}$ and $\mathrm{Ar}$ in air bubbles in an ice core. This technique provides constraints on decadal to centennial temperature fluctuations. We found that northern hemisphere temperature and Greenland temperature changed synchronously at periods of $\sim 20$ years and
\end{abstract}

T. Kobashi · J. P. Severinghaus $\cdot$ K. Kawamura

Scripps Institution of Oceanography, University of California,

San Diego, La Jolla, CA 92093, USA

T. Kobashi $(\bowtie)$

Institute for Global Environmental Strategies (IGES),

Hayama, Kanagawa, 240-0115 Japan

e-mail: kobashi@iges.or.jp

J.-M. Barnola

Laboratoire de Glaciologie et Géophysique de l'Environnement,

CNRS, Saint-Martin-d'Héres, France

K. Kawamura

National Institute of Polar Research, Itabashi-ku, Tokyo, Japan

T. Carter

Department of Anthropology, University of California,

San Diego, La Jolla, CA 92093, USA

T. Nakaegawa

Meteorological Research Institute,

Japan Meteorological Agency, Tsukuba, Japan 
40-100 years. This quasi-periodic multi-decadal temperature fluctuation persisted throughout the last millennium, and is likely to continue into the future.

\section{Introduction}

Most instrumental temperature records extend back only for 150 years (National Research Council (U.S.) Committee on Surface Temperature Reconstructions for the Last 2000 Years 2006), limiting our understanding of climate dynamics on a longer time scale. Therefore, many proxies for temperature have been developed to extend the temperature history (Hegerl et al. 2007; Jones and Mann 2004; Mann et al. 2008; Moberg et al. 2005; National Research Council (U.S.) Committee on Surface Temperature Reconstructions for the Last 2000 Years 2006). However, many of the proxies are qualitative and seasonally biased, and often the assumption of stationary relationships between the proxy and the short instrumental record cannot be verified (National Research Council (U.S.) Committee on Surface Temperature Reconstructions for the Last 2000 Years 2006). In Greenland, oxygen isotopes of ice (Stuiver et al. 1995) have been extensively used as a temperature proxy, but the data are noisy and do not clearly show multi-centennial trends for the last 1,000 years in contrast to borehole temperature records that show a clear "Little Ice Age" and "Medieval Warm Period" (Dahl-Jensen et al. 1998). Oxygen isotopes suffer known biases from factors other than temperature, such as the frequency of storm precipitation and the seasonality of precipitation (Stuiver et al. 1995). On the other hand, the resolution of the borehole surface temperature reconstruction is rapidly lost as time goes back, due to diffusion of heat (Alley and Koci 1990; Dahl-Jensen et al. 1998). Inert gas isotopes provide independent constraints in the decadal-centennial band that complement these traditional temperature proxies (Severinghaus et al. 1998).

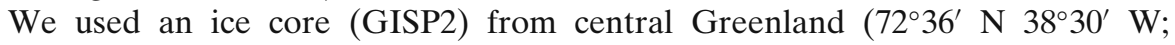
$3,203$ masl $)$, and analyzed nitrogen $\left({ }^{15} \mathrm{~N} /{ }^{14} \mathrm{~N}\right)$ and $\operatorname{argon}\left({ }^{40} \mathrm{Ar} /{ }^{36} \mathrm{Ar}\right)$ isotopic ratios (Kobashi et al. 2008b). Because these isotopic compositions are constant in the atmosphere for $>10^{5}$ years (Allegre et al. 1987; Mariotti 1983), deviations of these isotopic compositions in an ice core can be attributed to processes in the firn layer (unconsolidated snow layer on the top of glacial ice; 60-70 m thick in central Greenland) (Severinghaus et al. 1998). The thickness of the firn layer and the temperature gradient between the top and bottom of the firn layer causes known amounts of isotopic separation by gravitational and thermal fractionation, respectively (Severinghaus et al. 1998). Measurements of two isotopic ratios with differing sensitivity $\left(\delta^{15} \mathrm{~N}\right.$ and $\left.\delta^{40} \mathrm{Ar}\right)$ allow us to separate the two effects, providing the past firn thickness and temperature gradient $\Delta T$ (Kobashi et al. 2007, 2008a, b; Severinghaus and Brook 1999). Surface temperature can be calculated from the $\Delta T$ and accumulation rate data (Kobashi et al. 2008a), combined with a firn-densification/heat diffusion model (Goujon et al. 2003). The reconstructed temperature at central Greenland is a decadal average owing to smoothing of the record by gas diffusion in the firn and by the bubble close-off process. Notably, the record is not seasonally biased, and does not require any calibration to instrumental records, and resolves decadal to centennial temperature fluctuations. Therefore, this method provides a promising independent temperature history for the last 1,000 years. 


\section{Methodologies}

\subsection{Chronology}

We employed visual stratigraphy for the ice age chronology (Alley et al. 1997b). The uncertainty of the ice age is estimated to be 1\% (Alley et al. 1997b). The gas age is calculated by the Goujon model (Goujon et al. 2003) with inputs of surface temperature from calibrated oxygen isotopes of ice (Cuffey and Clow 1997) and accumulation rate (Alley et al. 1997b; Cuffey and Clow 1997). The additional gas age uncertainty is estimated to be $10 \%$ of the gas-ice age difference or 20 years (the gas-ice age difference is $200 \pm 4$ years for the last 1,000 years, varying with changes in firn condition).

\subsection{Data description}

Argon and nitrogen isotopes $\left(\delta^{15} \mathrm{~N}\right.$ and $\left.\delta^{40} \mathrm{Ar}\right)$, and argon/nitrogen ratio $\left(\delta \mathrm{Ar} / \mathrm{N}_{2}\right)$ in air trapped in the GISP2 ice core have been analyzed for the last 11,600 years (Kobashi 2007; Kobashi et al. 2007, 2008a, b). The detailed methodologies for the isotopic analyses and comprehensive description of data quality are presented elsewhere (Kobashi et al. 2008b). Special efforts were made for the last 1,000 years with higher-resolution (10-year) and higher-precision analyses (Kobashi et al. 2008b) (Fig. 1). A total of 275 samples from 97 depths were analyzed for the period 10001950 C.E. (Fig. 1). Pooled standard deviation of both $\delta^{15} \mathrm{~N}$ and $\delta^{40} \mathrm{Ar} / 4$ are $0.004 \%$. Therefore, the standard errors of means are $0.0023 \%$, $0.0028 \%$, and $0.004 \%$ o for the depths with triple, double, and single analyses, respectively. The pooled standard deviation of $\delta \mathrm{Ar} / \mathrm{N}_{2}$ is $0.65 \%$ o (Kobashi et al. 2008b).

\subsection{Surface temperature calculation}

Observed isotopic values can be decomposed into two components, $\delta^{40} \mathrm{Ar}_{\text {observed }}=$ $\delta^{40} \mathrm{Ar}_{\text {grav }}+\delta^{40} \mathrm{Ar}_{\text {therm }}$ and $\delta^{15} \mathrm{~N}_{\text {observed }}=\delta^{15} \mathrm{~N}_{\text {grav }}+\delta^{15} \mathrm{~N}_{\text {therm }}$, where grav and therm represent gravitational and thermal components (Kobashi et al. 2008b). The magnitude of gravitational fractionation linearly scales with mass difference (Craig et al. 1988). Therefore, we can write $\delta^{40} \mathrm{Ar}_{\text {grav }} / 4=\delta^{15} \mathrm{~N}_{\text {grav }}$. For simplicity, we will use $\delta^{40} \mathrm{Ar}_{\text {grav }} / 4$ for later discussion so that argon and nitrogen isotopes are on the same scale in terms of mass. Thermal components linearly relate to the temperature difference $(\Delta T)$ between the top and bottom of the firn layer. Therefore, $\delta^{15} \mathrm{~N}_{\text {therm }}=$ $\Delta T^{15} \Omega$ and $\delta^{40} \mathrm{Ar}_{\text {therm }}=\Delta T^{40} \Omega$ where ${ }^{15} \Omega$ and ${ }^{40} \Omega$ are laboratory-derived thermal coefficients (Grachev and Severinghaus 2003a, b). From these relationships, the past temperature gradient $\Delta T$ can be readily calculated from observed nitrogen and argon isotopic ratios as $\Delta T=\left(\delta^{15} \mathrm{~N}_{\text {observed }}-\delta^{40} \mathrm{Ar}_{\text {observed }} / 4\right) /\left({ }^{15} \Omega-{ }^{40} \Omega / 4\right)$. Recent studies have shown that there may be a third isotopic fractionation associated with gas loss, especially for those gases with smaller molecular sizes $(<3.6 \AA$ ') (Huber et al. 2006; Kobashi et al. 2008b; Severinghaus and Battle 2006; Severinghaus et al. 2003). We found strong evidence that argon isotopes are affected by gas loss (see later discussion). Therefore, we corrected $\delta^{40} \mathrm{Ar}$ using measured $\delta \mathrm{Ar} / \mathrm{N}_{2}$ following a previously established method (Severinghaus et al. 2003). 

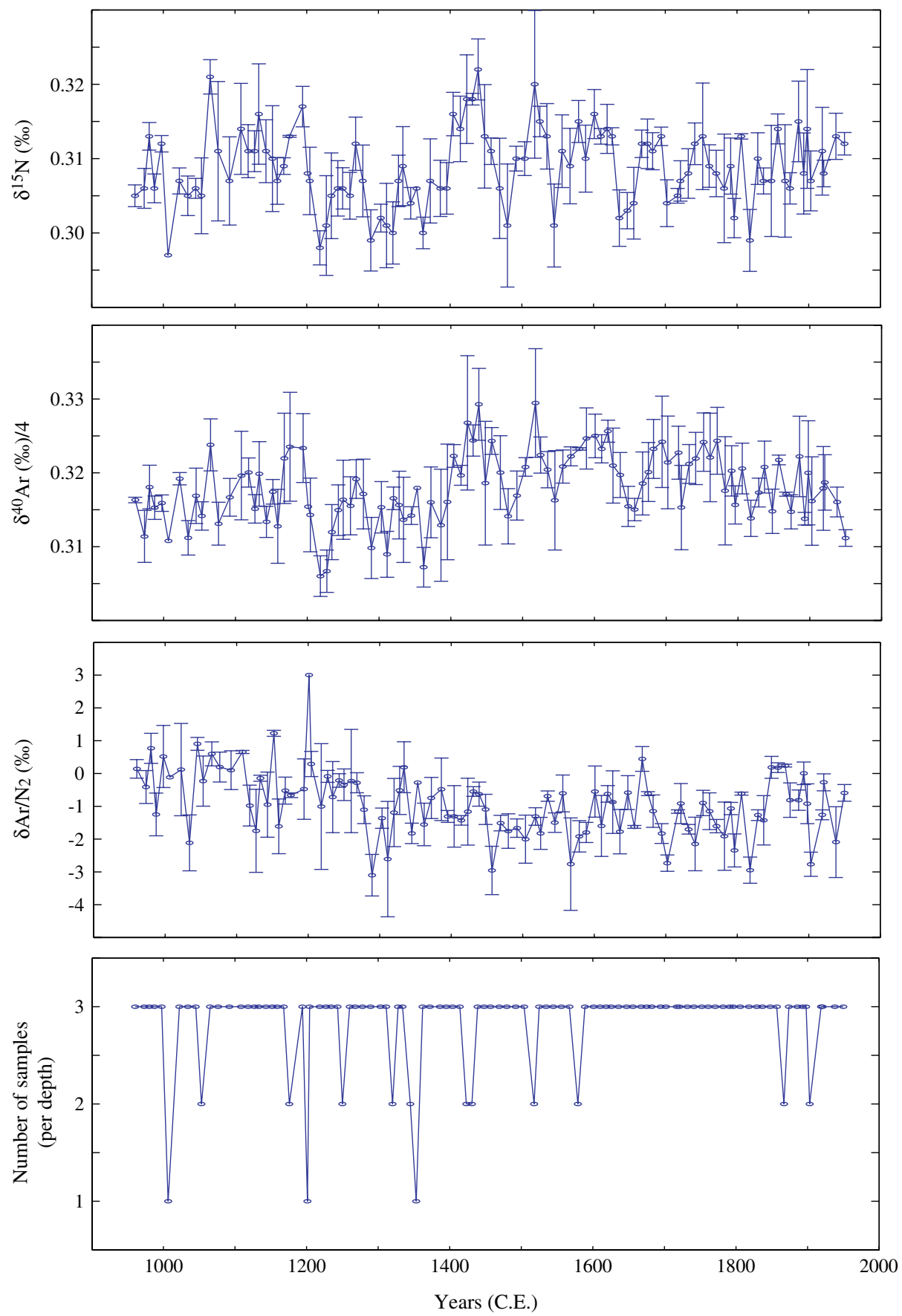

Fig. 1 Observed $\delta^{15} \mathrm{~N}, \delta^{40} \mathrm{Ar}, \delta \mathrm{Ar} / \mathrm{N}_{2}$, and number of samples per depth. The circles are means, and error bars are $1 \sigma$ standard deviation of replicate samples. Three depths are represented by a single analysis, and so are shown only by circles without error bars 
Firn conditions such as densification rate and heat transport are controlled by snow accumulation and surface temperature change (Goujon et al. 2003; Schwander et al. 1997). Therefore, it is possible to numerically calculate the past firn condition with empirical glaciological models if surface temperature and accumulation rate are known (Goujon et al. 2003; Schwander et al. 1997). Goujon et al. (2003) developed such a model to calculate the past firn condition based on a $\delta^{18} \mathrm{O}_{\text {ice }}$-derived surface temperature calibrated with the borehole temperature record (Alley et al. 1997a; Cuffey and Clow 1997) and accumulation rate (Cuffey and Clow 1997). The model also calculates the resultant isotopic fractionation of $\delta^{15} \mathrm{~N}$ and $\delta^{40} \mathrm{Ar}$ in the firn. Goujon et al. found that the observed $\delta^{15} \mathrm{~N}$ and $\delta^{40} \mathrm{Ar}$ are reproduced reasonably well with the $\delta^{18} \mathrm{O}$-based temperature for the transition from the last glacial period to the Holocene in Greenland (Goujon et al. 2003; Kobashi et al. 2008b). The model is also found to reproduce current firn conditions well over a range of environmental conditions (Landais et al. 2006). One exception is that the model fails to generate the observed isotopic signals $\left(\delta^{15} \mathrm{~N}\right.$ and $\left.\delta^{40} \mathrm{Ar}\right)$ at Antarctic sites such as Vostok with very cold and low accumulation during the last glacial (Goujon et al. 2003; Landais et al. 2006).

The temperature gradient $(\Delta T)$ in the firn is constantly modified by changes in surface temperature and heat transport in firn and ice. As heat transport in the firn is much slower than gas diffusion, temperature gradient data $(\Delta T)$ derived from observed $\delta^{15} \mathrm{~N}$ and $\delta^{40} \mathrm{Ar}$ can be used to calculate the heat transport in the firn if combined with accumulation rate data. Therefore, a surface temperature history can be calculated from the $\Delta T$ history if the initial temperature profile of the firn and ice sheet is known (Kobashi et al. 2008a, b). We used a borehole calibrated $\delta^{18} \mathrm{O}_{\text {ice }}$-based surface temperature record (Cuffey and Clow 1997; Stuiver et al. 1995) to create an initial temperature profile (Severinghaus and Brook 1999). Actual calculation in the model is conducted as follows. In a model year, the firn condition is forced by a new surface temperature and accumulation rate. In the second model year, a new surface temperature ( $T \mathrm{~s})$ is obtained by adding $\Delta T$ from observed isotopic records to the temperature $(\mathrm{Tb})$ at the bottom of the firn layer in the previous year model run (Kobashi et al. 2008a, b).

$$
T \mathrm{~s}=T \mathrm{~b}(\text { model output from the previous model year })+\Delta T \text { (observation) } .
$$

This calculation effectively takes the heat transport into account, and calculates a surface temperature from observed $\Delta T$ and accumulation rate.

\subsection{Surface temperature of the last 50 years}

Our latest data for isotopes is 1950 C.E. as the air occlusion process is not completed for recent decades. For the period 1950-1993, the surface temperature is estimated heuristically by a forward model (Goujon et al. 2003) running various surface temperature scenarios to find the best fit with the borehole temperature record. The method is in principle the same as that used by Alley and Koci (1990) (Fig. 2). The reconstructed temperature is generally similar to the instrumental temperature trend (Vinther et al. 2006) (Fig. 3), and temperature reconstruction by Alley and Koci (1990) (Fig. 2). The use of the Alley and Koci temperature reconstruction from 1950 onward creates a slight deviation from observed borehole temperature in the upper $80 \mathrm{~m}$ by $<0.3^{\circ} \mathrm{C}$. 
Fig. 2 Temperature

reconstructions after 1950 by Alley and Koci (1990) (blue) and this study (green). Dotted lines are the ending years of the calculations (1989 for Alley and Koci and 1993 for this study)

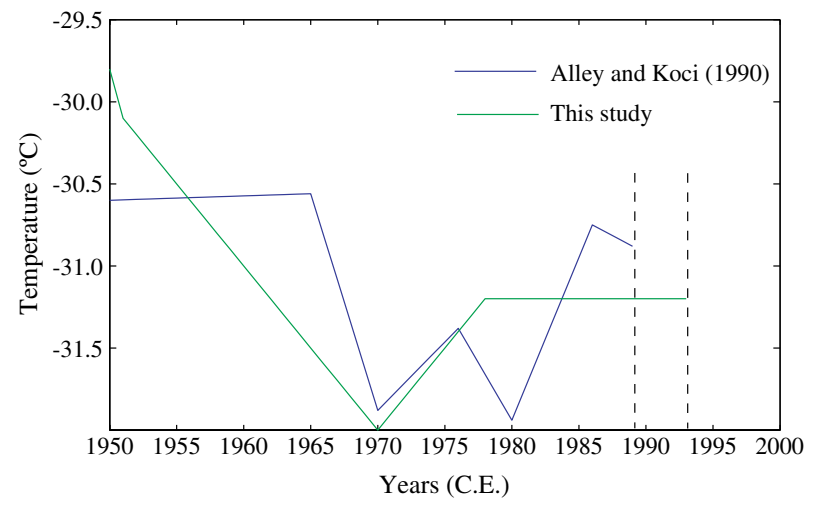

\section{5 $\Delta T$-based temperature calculation}

To apply the $\Delta T$-based surface temperature calculation, a prerequisite is to know the initial temperature profile of the firn and ice sheet. To accomplish this, we run the model from 24,300 B.P. (Before Present, present is defined as 1950 C.E.) until 2957 B.P. with the $\delta^{18} \mathrm{O}_{\text {ice }}$-based borehole-calibrated surface temperature (Cuffey and Clow 1997; Stuiver et al. 1995). This surface temperature reconstruction is known to be robust for a long-term trend (Goujon et al. 2003; Kobashi et al. 2008b). We employ the $\Delta T$-based surface temperature calculation from 2957 B.P. onward. The $\Delta T$-based surface temperature calculation produces $\delta^{15} \mathrm{~N}$ results more

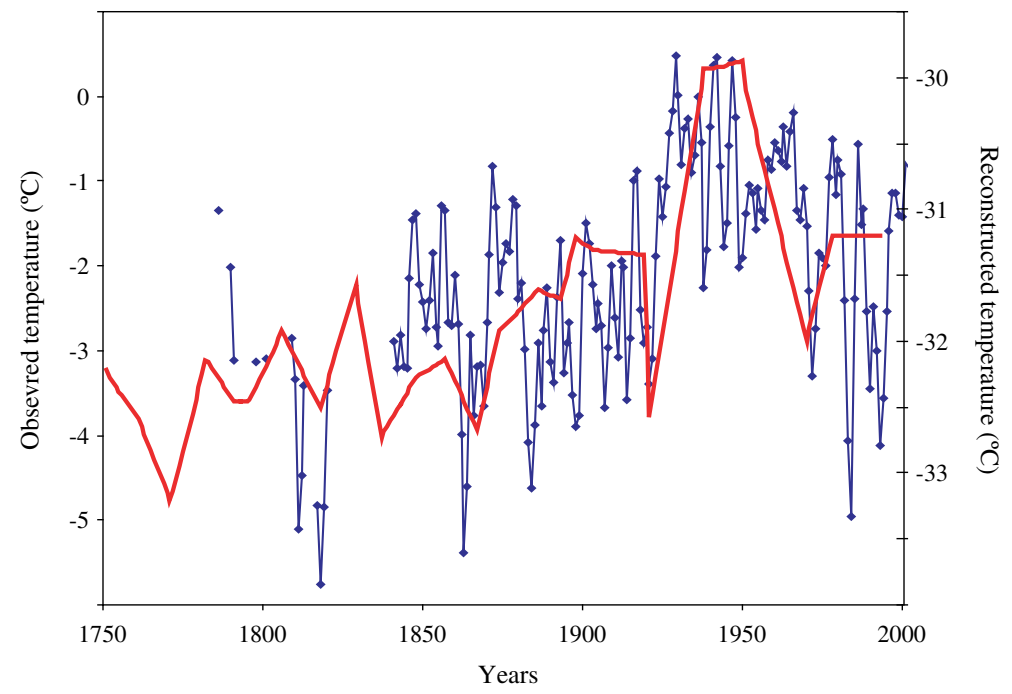

Fig. 3 Observed (blue) and reconstructed (red) Greenland temperature records. The observed record is a compilation of records from llulissat, Nuuk, and Qaqurtop located along the south and west coast of Greenland (Vinther et al. 2006). To smooth the observed data, a 2-year moving average is applied 
consistent with observed $\delta^{15} \mathrm{~N}$ for the period from 2957 to 1000 B.P. than the $\delta^{18} \mathrm{O}_{\text {ice }}{ }^{-}$ based calculation (Fig. 4). However, note that different temperature histories $\left(\delta^{18} \mathrm{O}\right.$ or $\Delta T$-based) before 1000 C.E. only slightly affect the first century of calculated surface temperature for the last 1,000 years. From 2957 B.P., the model calculation switches to the $\Delta T$-based calculation. As the Goujon model runs with a 1-year time step, an annual resolution $\Delta T$ time series is generated by linear interpolation. The data density (1 sample/20 years) from 2957 B.P. to 990 B.P. is about six times lower than that ( $\sim 3$ samples/10 years) for the last 1,000 years (Kobashi et al. 2008b) so that data is noisier.

At the end of the calculation, the temperature profile of the firn and ice sheet is compared with observed borehole temperature at GISP2 (Fig. 5) (Alley and Koci 1990; Clow et al. 1996). We combined two borehole records for the firn section, from Alley and Koci (1990) measured in summer 1989, and for the ice sheet section by Clow et al. (1996) measured in summer 1994. As the two temperature records show a slight offset in the overlapping depth, we shifted the Alley measurement by $+0.035^{\circ} \mathrm{C}$ to fit with the Clow data as the Clow thermometer has better accuracy. Also we adjusted the Alley temperature profile by lowering $9 \mathrm{~m}$ to align it with the Clow measurements, based on our expectation that the temperature profile moved downward during the five intervening years by new snow accumulation and temperature diffusion. The two data sets are combined at the depth of $230 \mathrm{~m}$.

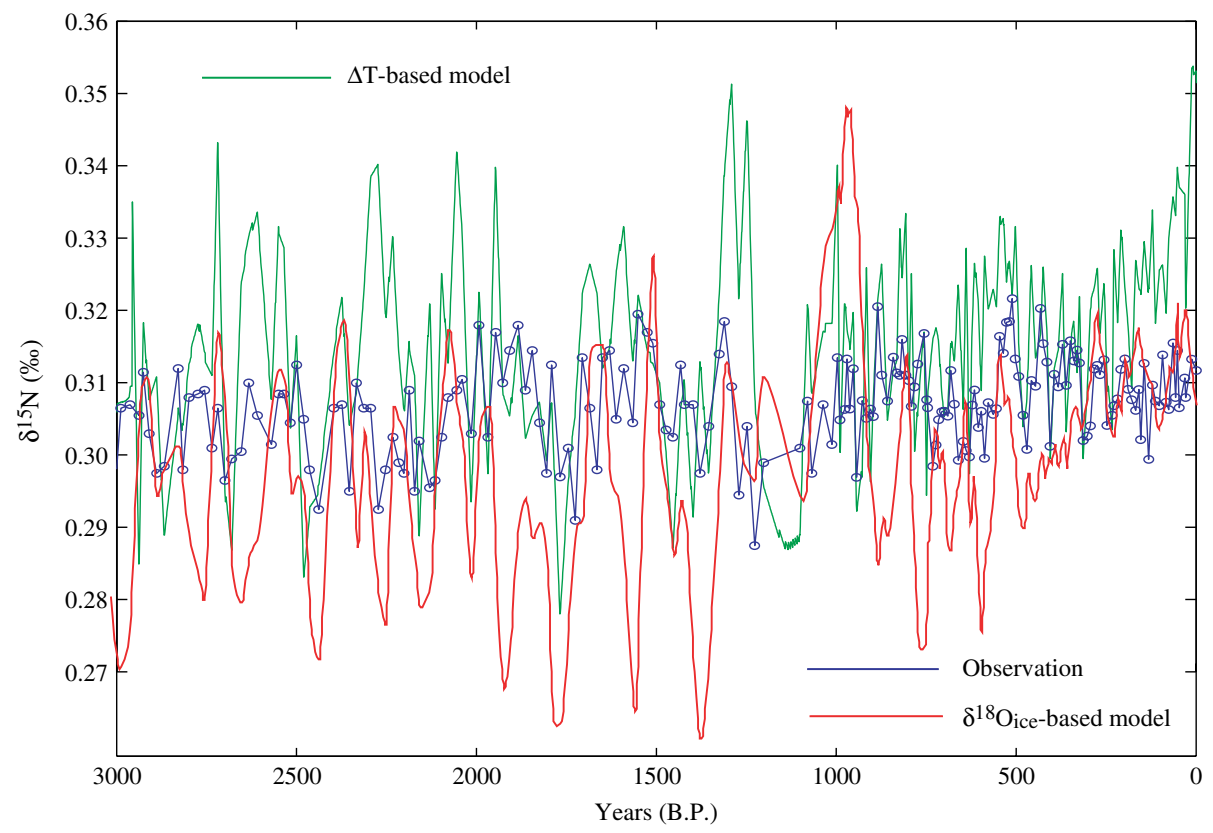

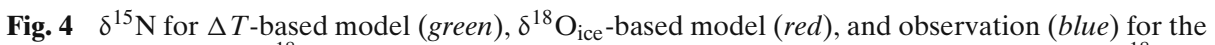
last 3,000 years. The $\delta^{18} \mathrm{O}_{\text {ice }}$-based model is based on the temperature reconstruction from $\delta^{18} \mathrm{O}$ of ice (Stuiver et al. 1995) calibrated from Cuffey and Clow (1997). The $\delta^{18} \mathrm{O}$ data is smoothed by a 50 -year running average. Note that the high resolution and precision data derived from nitrogen and argon isotopes start after 990 B.P. 
Fig. 5 Observed (red) (Clow et al. 1996) and modeled (blue) borehole temperature histories. Broken blue lines are $1 \sigma$ error bands

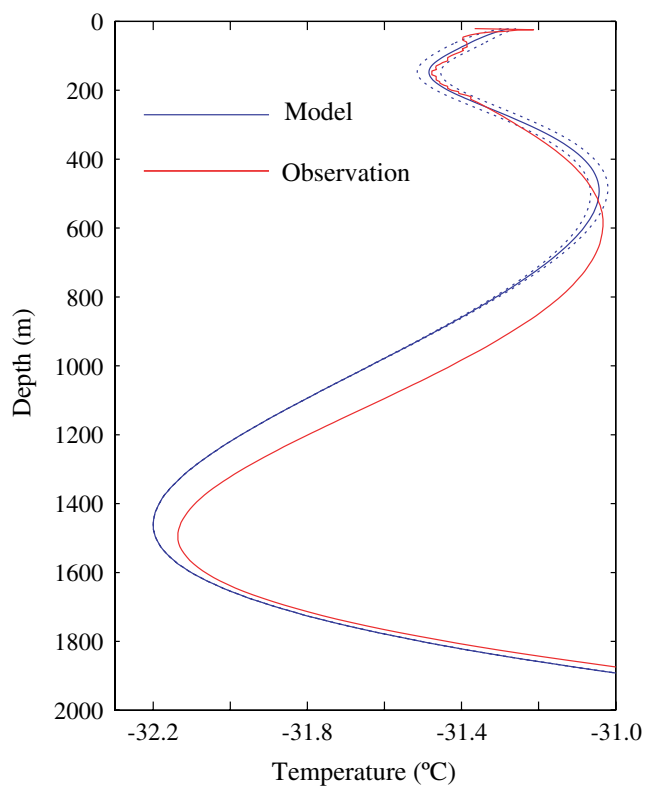

To estimate the error of the surface temperature calculation, we employed a Monte Carlo simulation from 960 to 1950 C.E. 800 synthetic $\Delta T$ time series were produced by adding white noise according to its analytical errors. Then, 800 surface temperature histories were generated from these $\Delta T$ time series. After each calculation of surface temperature, the temperature profile of the firn and ice sheet in the last model year is compared with the observed borehole temperature. Only those surface temperature histories $(n=102)$ with average root mean square temperature difference $\left(<0.05^{\circ} \mathrm{C}\right)$ in the upper $600 \mathrm{~m}$ of the ice sheet were used to calculate mean surface temperature and error for the last 1,000 years. The resultant surface temperature and its error are little changed by this selective process, but it substantially reduced errors in the reconstructed firn thickness. This reflects the fact that the surface temperature calculation is relatively insensitive to firn thickness variation in the model.

Modeled borehole temperature below $\sim 600 \mathrm{~m}$ is slightly colder than the observation by $<0.2^{\circ} \mathrm{C}$ (Fig. 5). This is likely due to the fact that the $\delta^{18}$ Oice-based surface temperature reconstruction used before 2957 B.P. is too cold, as can be seen in the modeled $\delta^{15} \mathrm{~N}$ being generally higher (corresponding to thicker firn thickness and colder overall firn temperature) than observed $\delta^{15} \mathrm{~N}$ before 2957 B.P. owing to colder firn temperature (Fig. 6). This offset has negligible impact on the temperature reconstruction for the last 1,000 years.

The absolute temperature in the $\Delta T$-based surface temperature calculation is sensitive to the initial absolute temperature of the firn, as the input $\Delta T$ has only relative temperature information. On the other hand, the $\Delta T$-based surface temperature "change" is less sensitive to the initial absolute temperature. Therefore, the

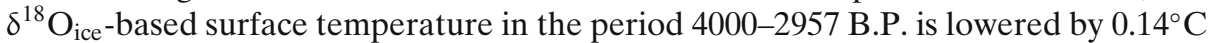
to decrease the $\Delta T$-based temperature history such that the final temperature profile fits with the observed borehole temperature record. 


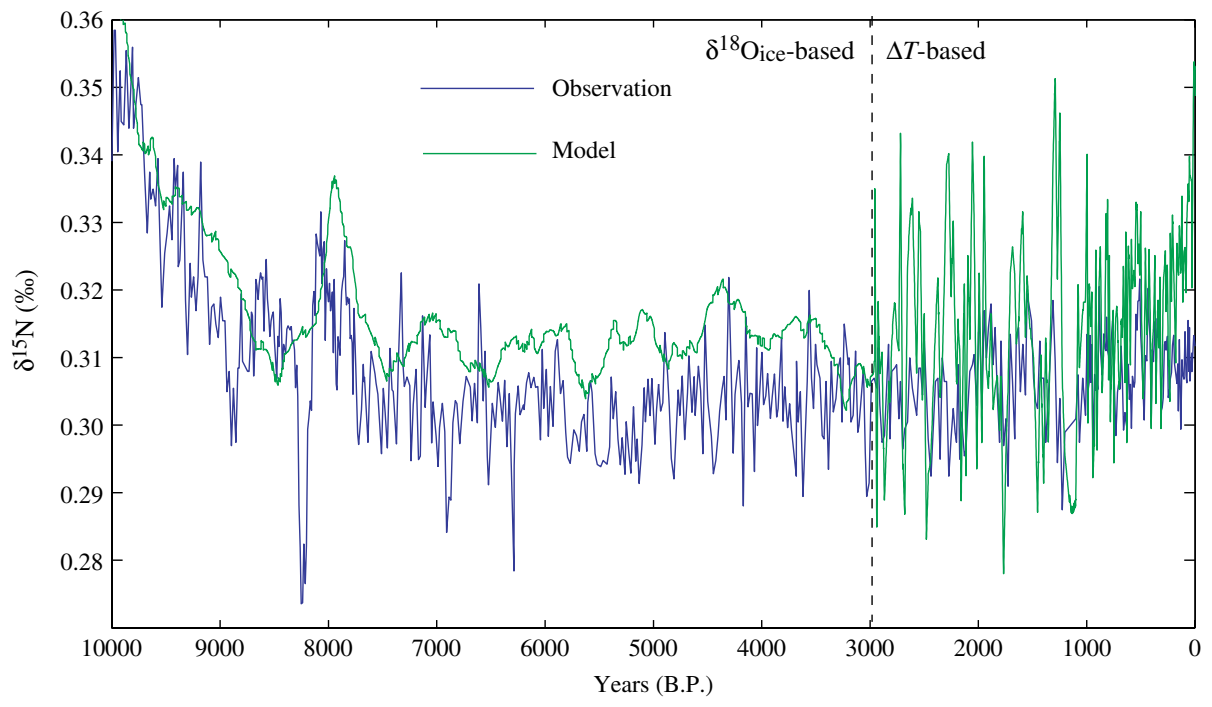

Fig. 6 Modeled (green) and observed (blue) $\delta^{15} \mathrm{~N}$ for the past 10,000 years. Note that the model result overestimates observed $\delta^{15} \mathrm{~N}$ before 3000 B.P., suggesting that the $\delta^{18} \mathrm{O}_{\text {ice }}$-based surface temperature (firn thickness) in the model is too cold (thick) before 3000 B.P. The model calculation switches from the $\delta^{18} \mathrm{O}_{\text {ice }}$-based to the $\Delta T$-based calculation at $\sim 3000$ B.P.

\subsection{Correction for gas loss impacts on isotopes}

The observed $\delta^{40} \mathrm{Ar} / 4$ data for the last 10,000 years show generally higher values than $\delta^{15} \mathrm{~N}$ by $0.01 \%$ o to $0.005 \%$, implying a negative temperature gradient $(\Delta T)$ in the firn of $-1^{\circ} \mathrm{C}$ to $-2^{\circ} \mathrm{C}$ for the past 10,000 years. However, a model study (Goujon et al. 2003) showed that the long term average temperature gradient in the firn layer should have been near zero in central Greenland for the last 8,000 years owing to high accumulation rate and relatively stable climate. This may be explained by the observation that the relatively small argon molecules leak out of the ice during/after coring, leaving heavier isotopes behind in the bubbles (Huber et al. 2006; Kobashi et al. 2008b; Severinghaus and Battle 2006; Severinghaus et al. 2003).

Measured $\delta \mathrm{Ar} / \mathrm{N}_{2}$ (mass $40 / 29$ ratio) provides information on preferential argon loss, as nitrogen (with larger molecular size) is fairly conservative with regard to potential artifacts (Severinghaus and Battle 2006; Severinghaus et al. 2003). $\delta \mathrm{Ar} / \mathrm{N}_{2}$ in the atmosphere should have been nearly constant $(<0.03 \%$; M. Headly, personal communication) for the last 1,000 years as ocean temperature (or heat content) only varied by $<0.1^{\circ} \mathrm{C}$ ( or $\sim 5.0 \times 10^{23} \mathrm{~J}$; Crowley et al. 2003). Therefore, the observed variation of $\delta \mathrm{Ar} / \mathrm{N}_{2}$ by as much as $3 \%$ in the ice core (Fig. 1) must have originated after the air was removed from the atmosphere.

$\delta \mathrm{Ar} / \mathrm{N}_{2}$ in ice cores is also affected by gravitational and thermal fractionation in the firn layer. Therefore, $\delta \mathrm{Ar} / \mathrm{N}_{2}$ is corrected for these processes using measured $\delta^{15} \mathrm{~N}: \delta \mathrm{Ar} / \mathrm{N}_{2}$ corrected $=\delta \mathrm{Ar} / \mathrm{N}_{2}$ observed $-11 \times \delta^{15} \mathrm{~N}$ (The number of 11 is the ratio of the mass differences of the pairs described by $\delta \mathrm{Ar} / \mathrm{N}_{2}$ and $\delta{ }^{15} \mathrm{~N}$ (Kobashi et al. 2008b)). The slight difference in thermal coefficients of $\delta^{15} \mathrm{~N}$ and $\delta \mathrm{Ar} / \mathrm{N}_{2}$ is negligible 


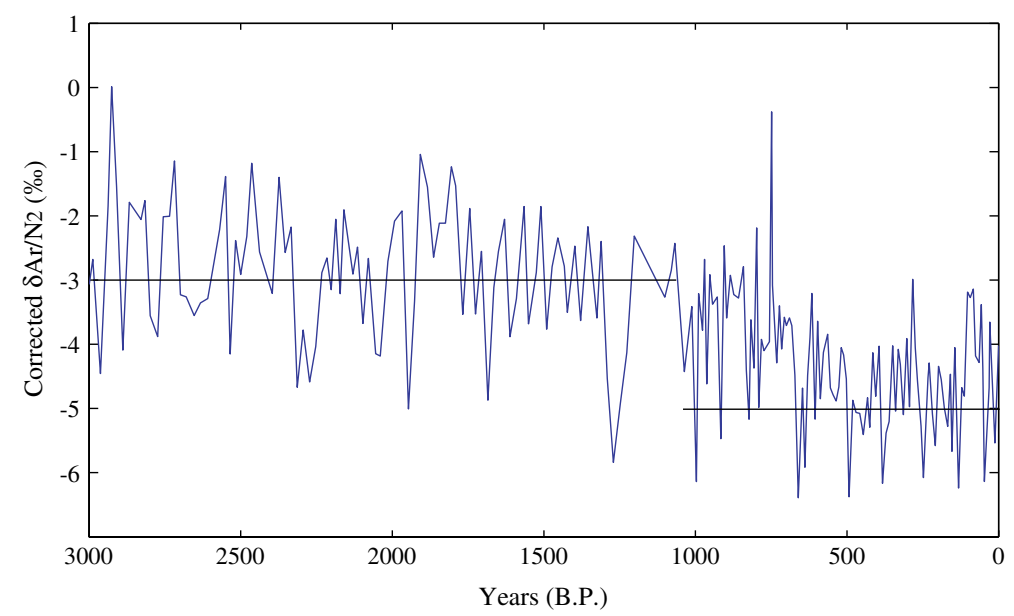

Fig. 7 Gas-loss-corrected $\delta \mathrm{Ar} / \mathrm{N}_{2}$. Note the decrease in mean value around 1000 C.E. from $-3 \%$ to $-5 \%$, suggesting that argon loss was more extensive for shallower ice

for the purpose of this correction. The corrected $\delta \mathrm{Ar} / \mathrm{N}_{2}$ is used as an indicator of argon loss.

It has been suggested that an argon leak through microcracks in the ice may be associated with isotopic fractionation with an enrichment of $\delta^{40} \mathrm{Ar}$ by $\sim 0.007 \%$ per $1 \%$ increase in $\delta \mathrm{Kr} / \mathrm{Ar}$ (Severinghaus et al. 2003). $\delta \mathrm{Kr} / \mathrm{Ar}$ and $\delta \mathrm{N}_{2} / \mathrm{Ar}$ are thought to be very similar after gravitational correction (Severinghaus et al. 2003). Therefore, the corrected $\delta \mathrm{Ar} / \mathrm{N}_{2}$ values of $-6 \%$ to $-1 \%$ in the interval from 3000 B.P. to 0 B.P. (Fig. 7), imply potential impacts on $\delta^{40} \mathrm{Ar} / 4$ of as much as $0.01 \%$ (Fig. 8). In addition, the corrected $\delta \mathrm{Ar} / \mathrm{N}_{2}$ shows a gradual decrease from 1000 B.P. to 500 B.P. (Fig. 7), implying that more pronounced argon leakage occurred in the shallower ice. We corrected $\delta^{40} \mathrm{Ar}$ for gas-loss effects using the corrected $\delta \mathrm{Ar} / \mathrm{N}_{2}: \delta^{40} \mathrm{Ar}_{\text {corrected }}=$ $\delta^{40} \mathrm{Ar}_{\text {observed }}+0.0075 \times \delta \mathrm{Ar} / \mathrm{N}_{2}$ corrected. The coefficient 0.0075 is obtained by running the $\Delta T$-based surface temperature calculation with various coefficients and comparing the outputs with the borehole temperature record and observed $\delta^{15} \mathrm{~N}$. The coefficient is close to the value of 0.007 found for the Siple Dome ice core (Severinghaus et al. 2003). The correction lowers $\delta^{40} \mathrm{Ar}$ and raises $\Delta T$, but the decadal to centennial fluctuations are mostly preserved (Fig. 8). The fact that the $\Delta T$ surface temperature calculation runs without drift for 3,000 years (small errors in $\Delta T$ create large drifts in calculated surface temperature during the integration), and the fact that the modeled borehole temperature and $\delta^{15} \mathrm{~N}$ agree with observations, supports the validity of the $\delta^{40} \mathrm{Ar}$ correction.

Evidence for impacts of argon loss on $\delta^{40} \mathrm{Ar}$ can also be inferred from the following experiments. We ran the model by shifting $\Delta T$ by a constant $1.8-1.9^{\circ} \mathrm{C}$. to produce a surface temperature history for the last 1,000 years consistent with observed borehole records. We also performed a $\Delta T$-based surface temperature calculation for the period $3000-1000$ B.P. with the same $\Delta T$ shift of $1.8-1.9^{\circ} \mathrm{C}$, and found that this creates a large drift (increasing temperature through this period) and a resultant $\delta^{15} \mathrm{~N}$ inconsistent with observed $\delta^{15} \mathrm{~N}$. However, a constant $\Delta T$ shift by $1^{\circ} \mathrm{C}$ for the period $3000-1000$ B.P. produced a consistent picture. Therefore, it is 


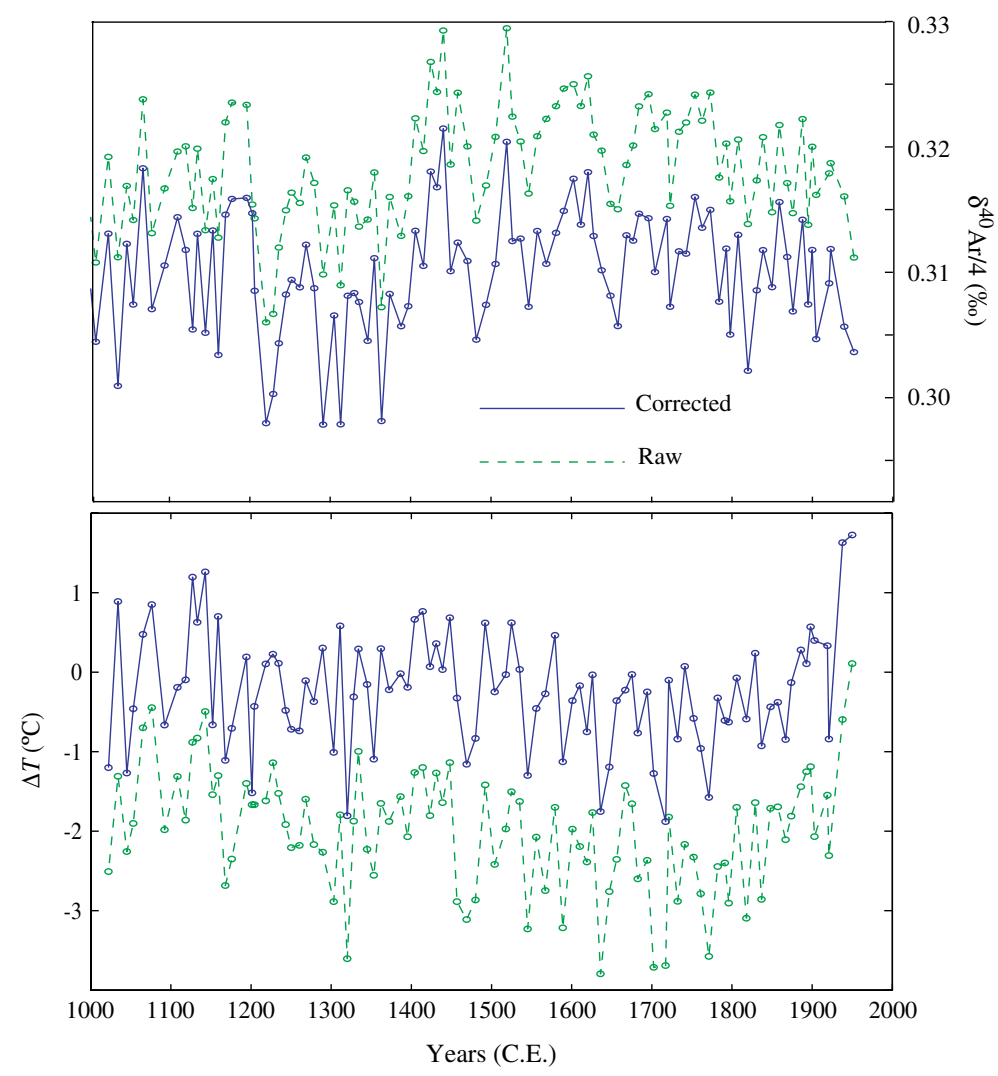

Fig. 8 Raw (green) and corrected (blue) $\delta^{40} \mathrm{Ar}$ and $\Delta T$. Note that the multi-decadal to centennial fluctuations are little affected by the correction

clear that the magnitude of artifacts on $\delta^{40} \mathrm{Ar}$ changed around 1000 B.P., which is consistent with the $\delta \mathrm{Ar} / \mathrm{N}_{2}$ data. We plot the two alternative surface temperature histories (Fig. 9) using $\Delta \mathrm{T}$ corrected by a constant shift and $\delta^{40} \mathrm{Ar}$ corrected by $\delta \mathrm{Ar} / \mathrm{N}_{2}$. Both histories show similar multi-decadal to centennial trends, except for a slightly higher temperature in the Medieval Warm Period by $\sim 0.5^{\circ} \mathrm{C}$ with the $\Delta T$ constant shift. Therefore, the centennial to multi-decadal trends in the reconstructed temperature appear to be a robust feature.

\subsection{Firn thickness change from gas isotopes: model vs. observation}

The model (driven by $\delta \mathrm{Ar} / \mathrm{N}_{2}$ corrected $\delta^{40} \mathrm{Ar}$ ) shows a gradual increase of firn thickness by $\sim 3 \mathrm{~m}$ through the last millennium (Fig. 10), reflecting the reduced densification rate due to the cooling from the Medieval Warm Period to the Little Ice Age. The last 150 years of warming are not significantly reflected in the firn thickness owing to slow heat diffusion in the firn. The past firn thickness change should be reflected as an increase in the gravitational component of observed $\delta^{15} \mathrm{~N}$ (Fig. 11). Observed $\delta^{15} \mathrm{~N}_{\text {grav }}$ shows the expected magnitude of increase toward the 


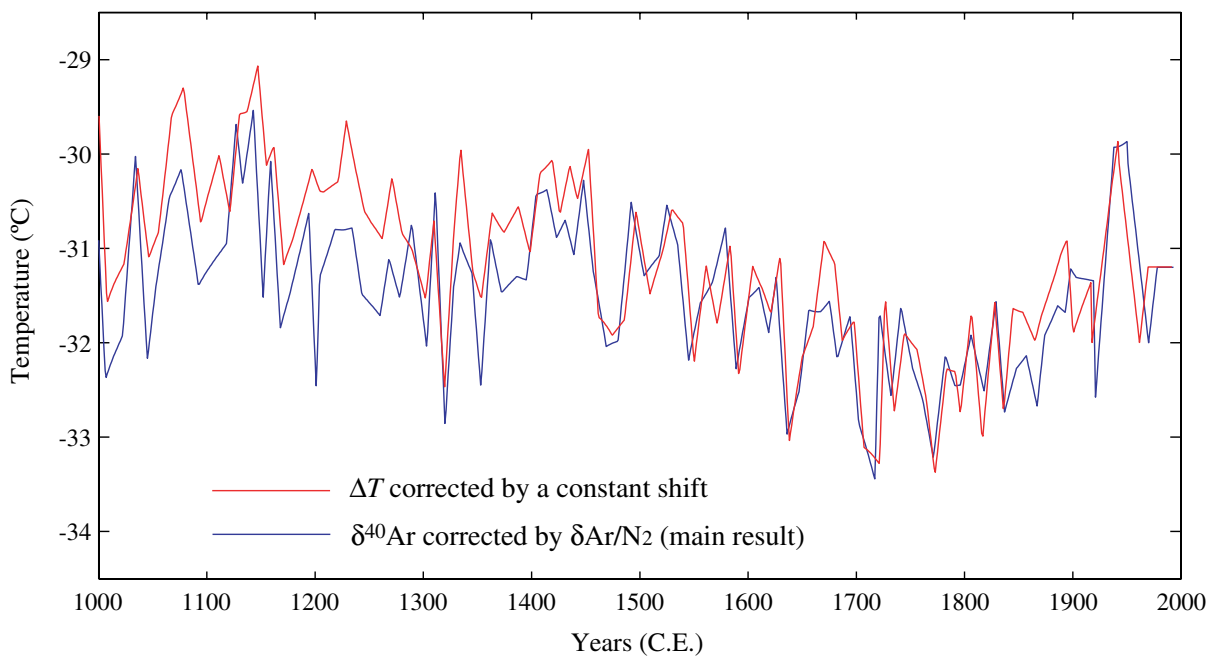

Fig. 9 Surface temperature reconstruction with the $\Delta T$ corrected by a constant shift (red) and by the $\delta^{40} \mathrm{Ar}$ corrected with $\delta \mathrm{Ar} / \mathrm{N}_{2}$ (blue)

late millennium, but in the last 200 years observed $\delta^{15} \mathrm{~N}_{\text {grav }}$ shows a significant reduction, in contrast to the model result (Fig. 11). Discrepancies are also found around $1300-1500$ C.E. Observed $\delta^{15} \mathrm{~N}_{\text {grav }}$ shows more variation than the model $\delta^{15} \mathrm{~N}_{\text {grav }}$, although the variations are near the limit of analytical error. Observed and modeled $\delta^{15} \mathrm{~N}$ records also show overall agreement but with the same noticeable discrepancies (Fig. 12). As the thermal component of $\delta^{15} \mathrm{~N}$ is an input in the model as $\Delta T$, all discrepancies between the model and observed $\delta^{15} \mathrm{~N}_{\text {grav }}$ (Fig. 11) are also reflected in the model and observed $\delta^{15} \mathrm{~N}$ comparison (Fig. 12).

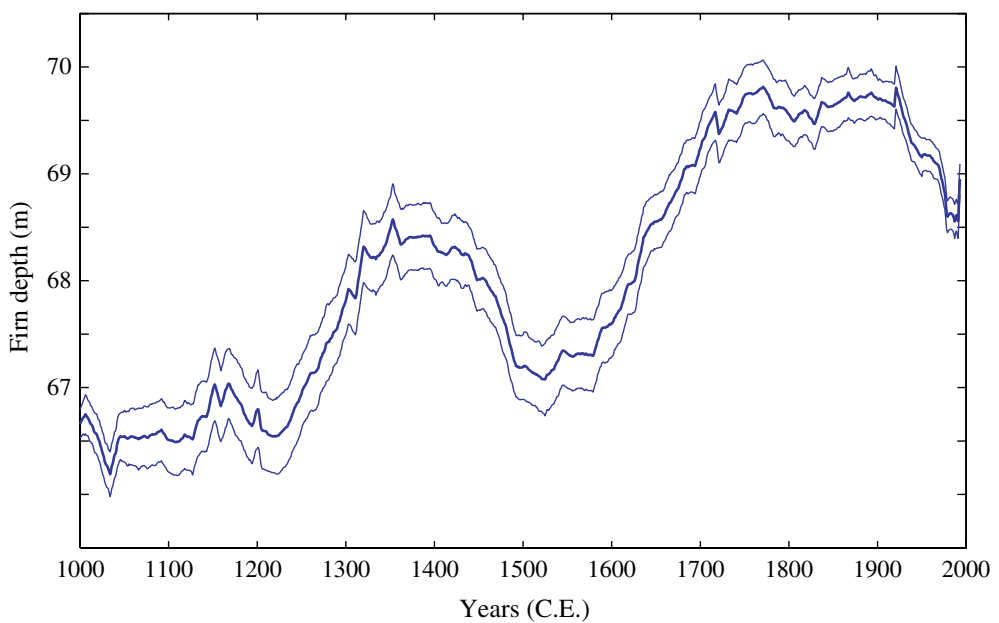

Fig. 10 Model result of firn depth for the last 1,000 years. The model firn depth increased $\sim 3 \mathrm{~m}$ $(5 \%)$ since the beginning of the millennium 


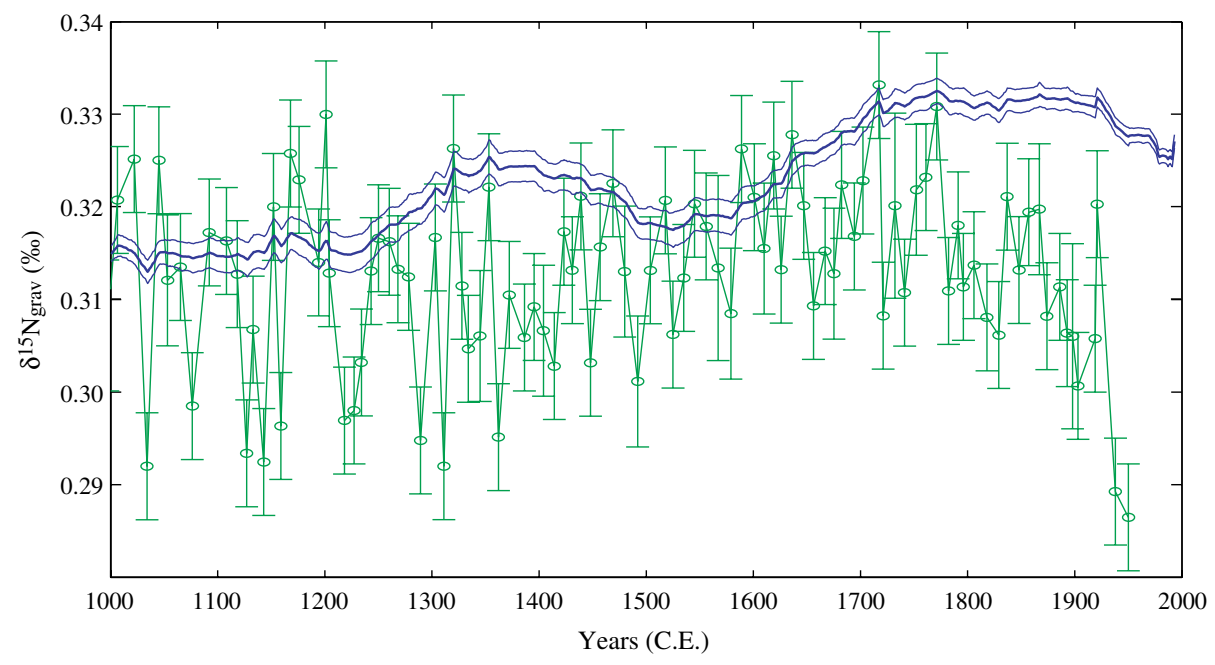

Fig. 11 Model (blue) and observed (green) gravitational component of $\delta^{15} \mathrm{~N}$ (or $\delta^{15} \mathrm{~N}_{\text {grav }}$ ) for the last 1,000 years

Accumulation rate data, which are also inputs in the model, may provide some insights on this discrepancy. We compared accumulation rate data between GISP2 (Alley et al. 1997b; Cuffey and Clow 1997) and composite data from three Greenland cores (DYE-3, GRIP, NGRIP) (Andersen et al. 2006) (Fig. 13). The GISP2 accumulation rate and composite data show little correlation $\left(r^{2}=0.04\right)$. It is known that accumulation rate can be considerably different even from two adjacent ice cores

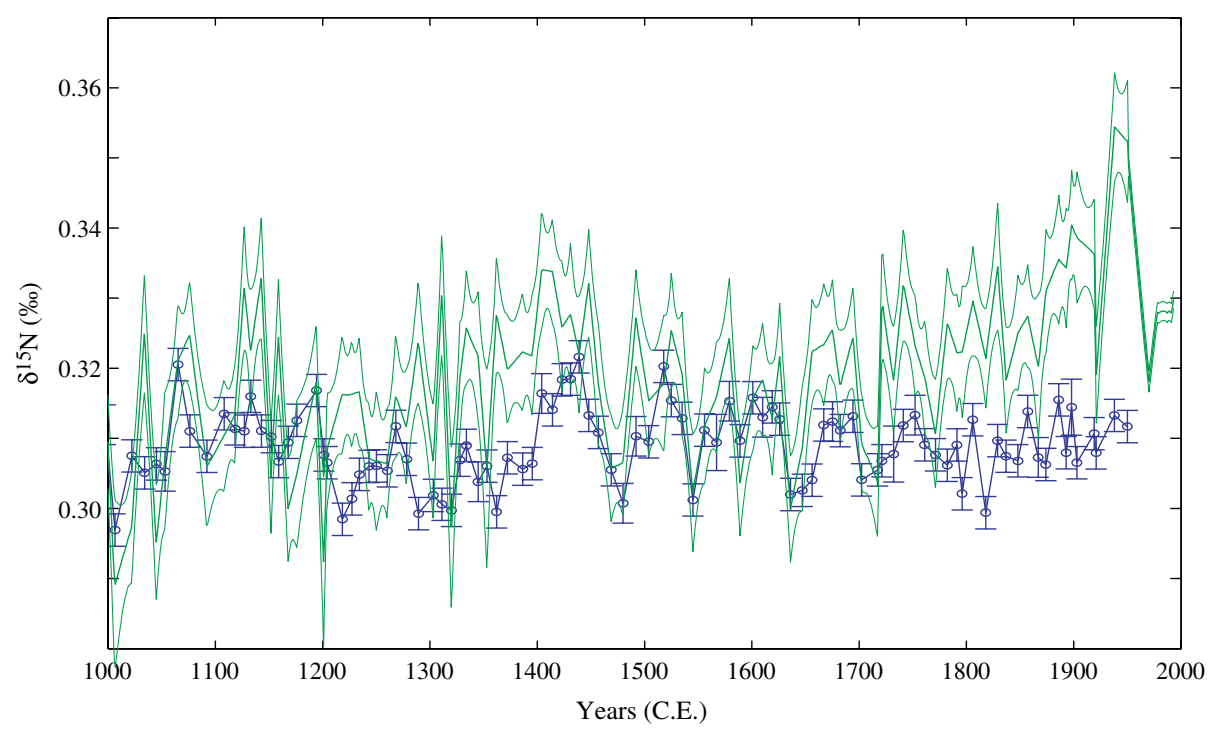

Fig. 12 Model (green) and observed (blue) $\delta^{15} \mathrm{~N}$ for the last 1,000 years 
owing to snow drifting (Fisher et al. 1985), suggesting that long term averaging or compilation of accumulation rate from various cores are required to obtain real accumulation signals. Notably, $\delta^{15} \mathrm{~N}$ shows more correlation $(r=0.36)$ with the composite accumulation history than with GISP2 accumulation data $(r=0.1)$.

The largest peak in $\delta^{15} \mathrm{~N}$ in the early fifteenth century is also the time of the highest snow accumulation in Greenland (Andersen et al. 2006). Some of the disagreements between the model and observed $\delta^{15} \mathrm{~N}$ occur in times of disagreements between GISP2 accumulation and composite data (Fig. 13). For example, the model overestimates observed $\delta^{15} \mathrm{~N}$ for 1100-1150, 1300-1400, and 1600-1750 (Fig. 12), when the GISP2 accumulation rate data is higher than composite estimates (Fig. 13). This may suggest that to reconstruct the firn thickness change more precisely it may be better to use the composite accumulation rate data. However, as the model firn thickness variation during the last millennium is small $(<5 \%)$, the use of the slightly different accumulation rate histories have little effects on the surface temperature calculation.
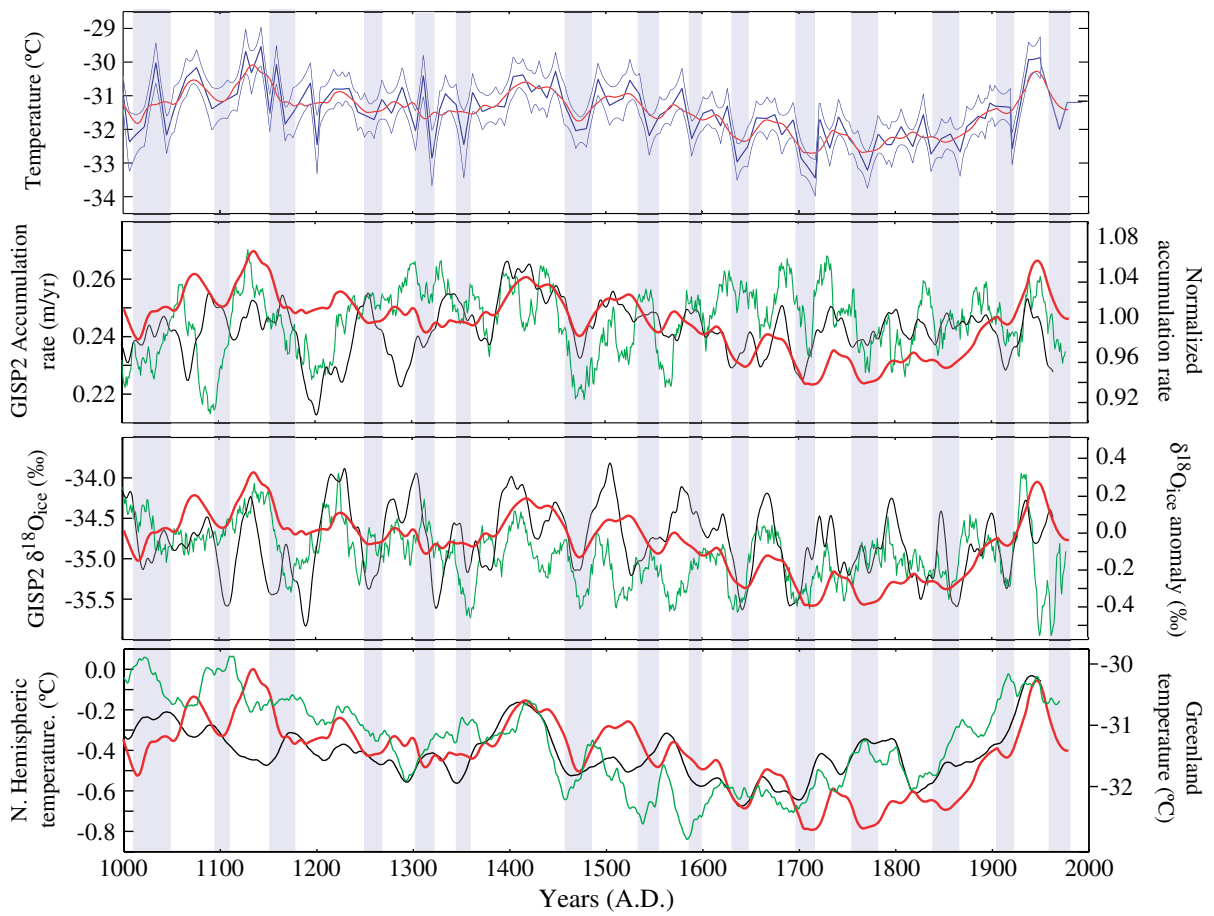

Fig. 13 Last-millennium records of comprehensive climate indicators. Temperature record on the top panel is the same as Fig. 1. Second panel shows GISP2 ice accumulation rate (green) (Alley et al. 1997b; Cuffey and Clow 1997) and stacked record (black) for Greenland accumulation rate from the DYE-3, GRIP, and NGRIP ice cores (Andersen et al. 2006). Data are smoothed with a 20-year running mean. Third panel shows GISP2 $\delta^{18} \mathrm{O}_{\text {ice }}$ (green) (Stuiver et al. 1995) and stacked record (black) for Greenland $\delta{ }^{18} \mathrm{O}_{\text {ice }}$ from the DYE-3, GRIP, and NGRIP ice cores (Andersen et al. 2006). Red lines in each panel are the Greenland temperature from the top panel with a 50-year running mean. Fourth panel shows northern hemisphere temperatures from Moberg et al. (2005) (green) and Hegerl et al. (2007) (black) with a 20-year running mean. Shaded areas are cooler periods as shown in the temperature records 
Fig. 14 Air content in ice for the last 1,000 years. The values are normalized to the mean value for the last 1,000 years

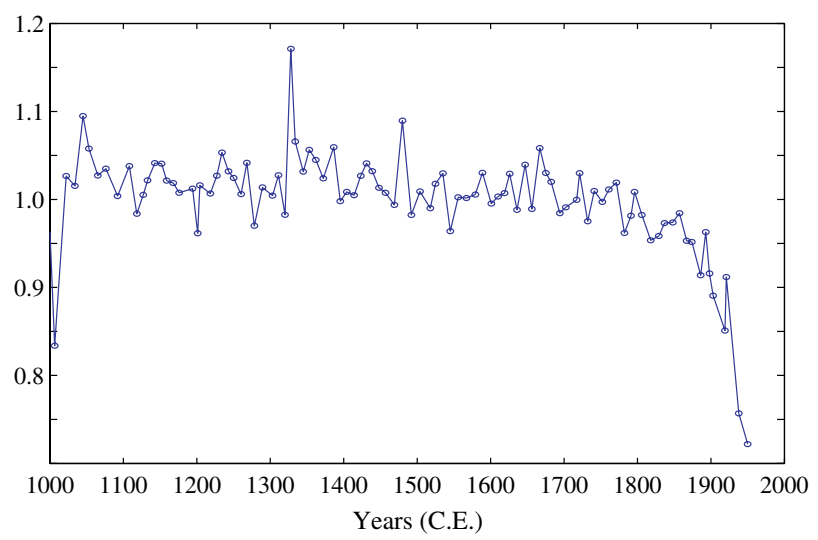

The observed $\delta^{15} \mathrm{~N}_{\text {grav }}$ shows a significant decrease from $\sim 1800$ onward, but model $\delta^{15} \mathrm{~N}_{\text {grav }}$ stayed relatively constant. This significant deviation may relate to the observed decrease in air content of shallow ice owing to incomplete bubble closure (Fig. 14), which may alter the gas isotopes (Severinghaus and Battle 2006). However, this isotopic fractionation should be similar to gravitational fractionation (Severinghaus and Battle 2006) so that the effects on isotopes should be canceled during the calculation of $\Delta T$. Firn thickness obtained from $\delta^{15} \mathrm{~N}_{\text {grav }}$ would be biased by this effect, so $\delta^{15} \mathrm{~N}_{\text {grav }}$ should be interpreted with caution in this interval.

Observed $\delta{ }^{15} \mathrm{~N}_{\text {grav }}$ shows more decadal variation than model results (Fig. 11). This may relate to inadequacies in the model representation of shallow firn. Recent shallow firn thickness studies show that conventional firn densification models may underestimate higher frequency variation (Li et al. 2003; Zwally and Jun 2002). Therefore, further research on shallow firn densification processes is needed.

\section{Greenland temperatures of the last 1,000 years}

For about the last 200 years, observed temperature records are available from south and west Greenland coastal sites (Vinther et al. 2006), allowing qualitative validation of our temperature reconstruction from central Greenland (Fig. 3). The observed temperature record shows multi-decadal temperature variation, a rapid warming around 1930, and the warmest decades of the last 200 years around 1940. This is followed by a cooling toward 1980, and a recent warming toward the present (Fig. 3). Considering the sampling interval of 10 years and uncertainty of $\pm 0.5^{\circ} \mathrm{C}$, these trends agree well with the reconstructed Greenland temperature record (Fig. 3). The earlier warming around 1930 is clearly shown in our record, and is also found in the surface temperature reconstruction from borehole temperature records from Greenland summit (Alley and Koci 1990; Dahl-Jensen et al. 1998). Figure 15 shows the reconstructed Greenland temperatures, global observed temperature anomalies for the last 130 years (NASA 2009) and reconstructed northern hemisphere temperature anomalies (Mann et al. 2008). It is clear that for the last 300 years, the reconstructed Greenland temperature trends are in agreement with hemispheric temperature trends except for the last 50 years (Fig. 15). 


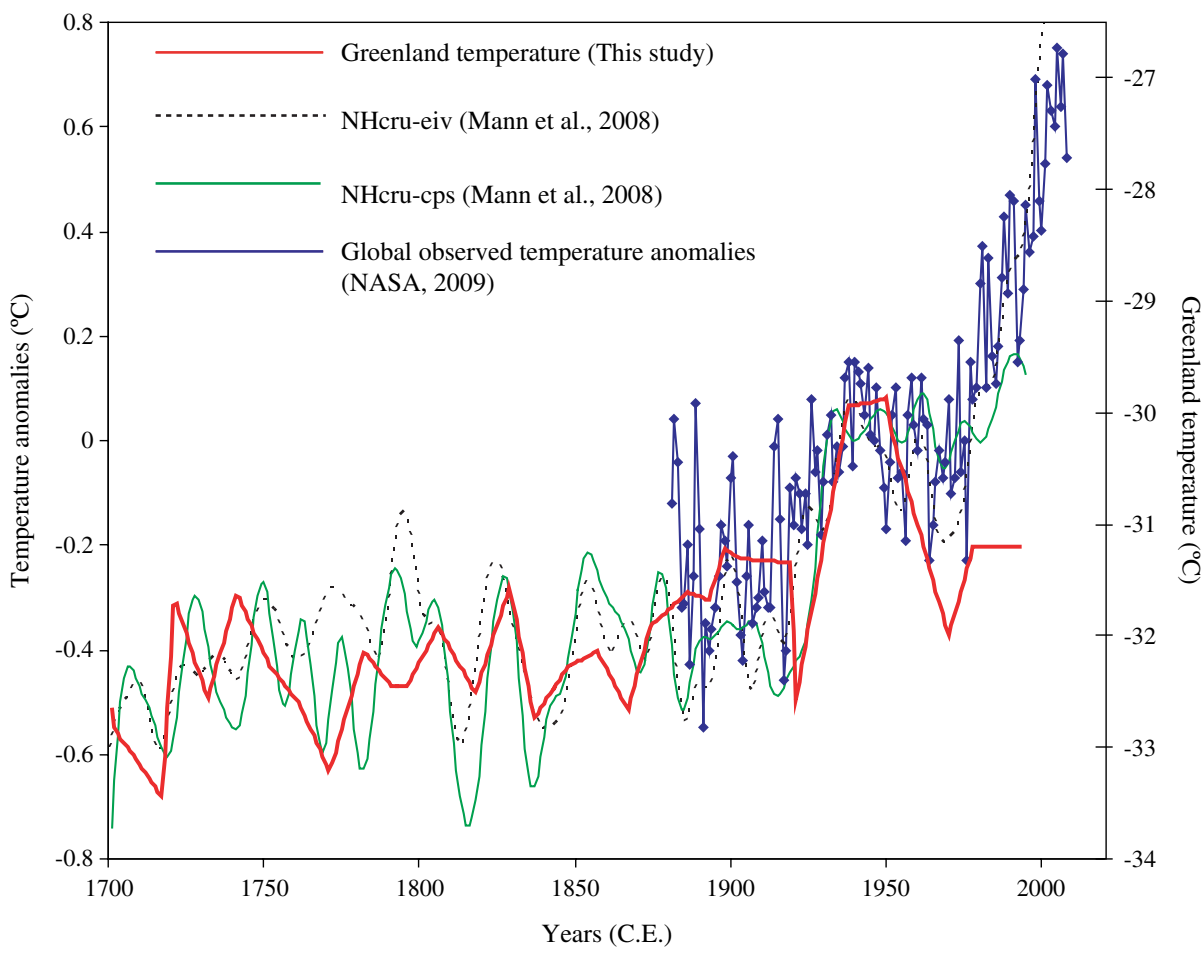

Fig. 15 Reconstructed Greenland temperature (red; this study), global observed temperature anomalies (blue) (NASA 2009), and reconstructed northern hemisphere temperature anomalies (EIV, dotted line; CPS, green) (Mann et al. 2008) for the last 300 years. One of the most recent reconstructions of northern hemisphere temperature for the last 2,000 years used two methods (EIV and CPS; see (Mann et al. 2008) for detail)

Reconstructed gas-based temperature shows a warmer period in the earlier part of the millennium and cooling toward the eighteenth century, and temperature increase from the late nineteenth century to the twentieth century (Fig. 16). This pattern is consistent with the well-known "Medieval Warm Period" and "Little Ice Age", and is similar to reconstructions of northern hemisphere temperature (Figs. 13 and 17) (Hegerl et al. 2006; Mann et al. 2008; Moberg et al. 2005). The average central Greenland temperature for the last 1,000 years is $-31.4^{\circ} \mathrm{C}$ with a minimum temperature of $-33.4^{\circ} \mathrm{C}$ in the early and late eighteenth century and a maximum temperature of $-29.5^{\circ} \mathrm{C}$ in the mid twelfth century and the early twentieth century (Fig. 16). The general trend is similar to previous central Greenland temperature reconstructions, based on borehole temperature records (Alley and Koci 1990; Cuffey and Clow 1997; Dahl-Jensen et al. 1998) (Fig. 18). A temperature history using borehole-calibrated $\delta^{18} \mathrm{O}_{\text {ice }}$, with two different oxygen isotope-temperaturesensitivities before $\left(0.25 \%{ }^{\circ} /{ }^{\circ} \mathrm{C}\right)$ and after $\left(0.47 \%\right.$ o $\left./{ }^{\circ} \mathrm{C}\right)$ after $1500 \mathrm{CE}$ (Cuffey and Clow 1997), shows larger variation with notable differences (Fig. 18).

At the beginning of the last millennium, Greenland climate was in a cooler period, and then the temperature warmed toward the middle of the twelfth century (which was the warmest century in the last 1,000 years). Then, temperature decreased 


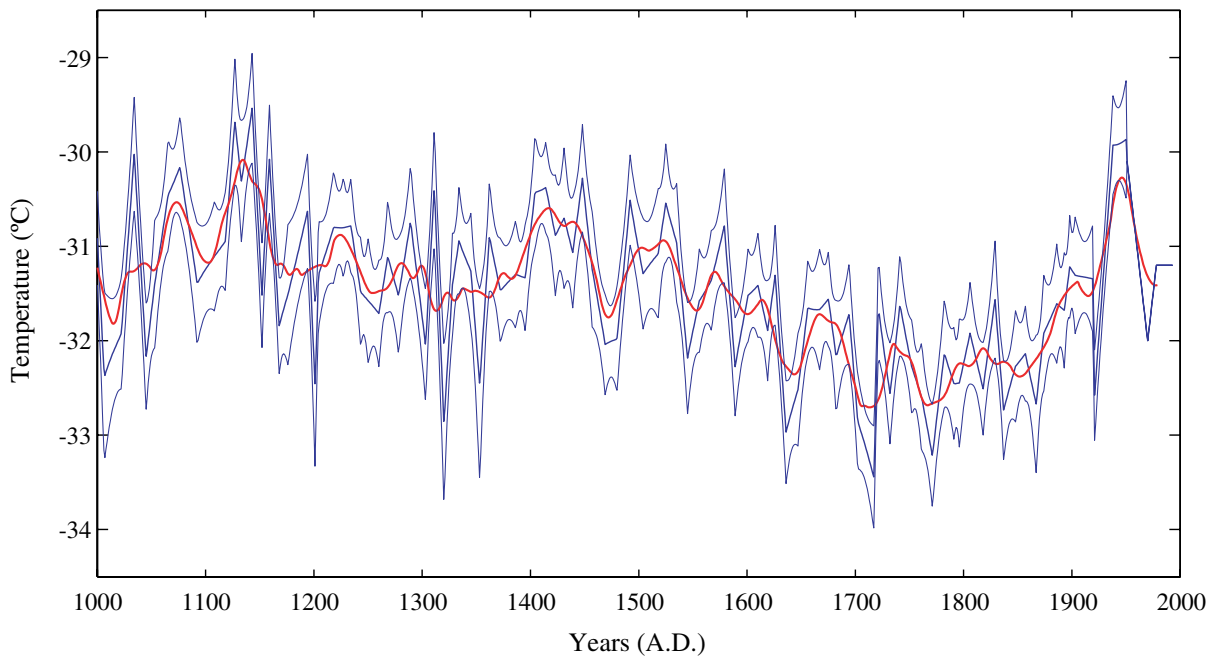

Fig. 16 The last 1,000 years of Greenland temperature derived from nitrogen and argon isotopes in air bubbles in ice. Thick blue line is mean of results of Monte Carlo simulation, and thin blue lines are error bands $(1 \sigma)$. Red line is a smoothed temperature history (50-year running mean)

toward $1300 \mathrm{CE}$. This early phase of the Little Ice Age coincides with an initial culmination of alpine glacier advances in the Northern Hemisphere (Grove 2001). Then, temperature increased again toward the early fifteenth century. From the middle fifteenth century onward, Greenland temperature began a 400-year long cooling trend with a clear multi-decadal oscillation (Fig. 16). Around this time,

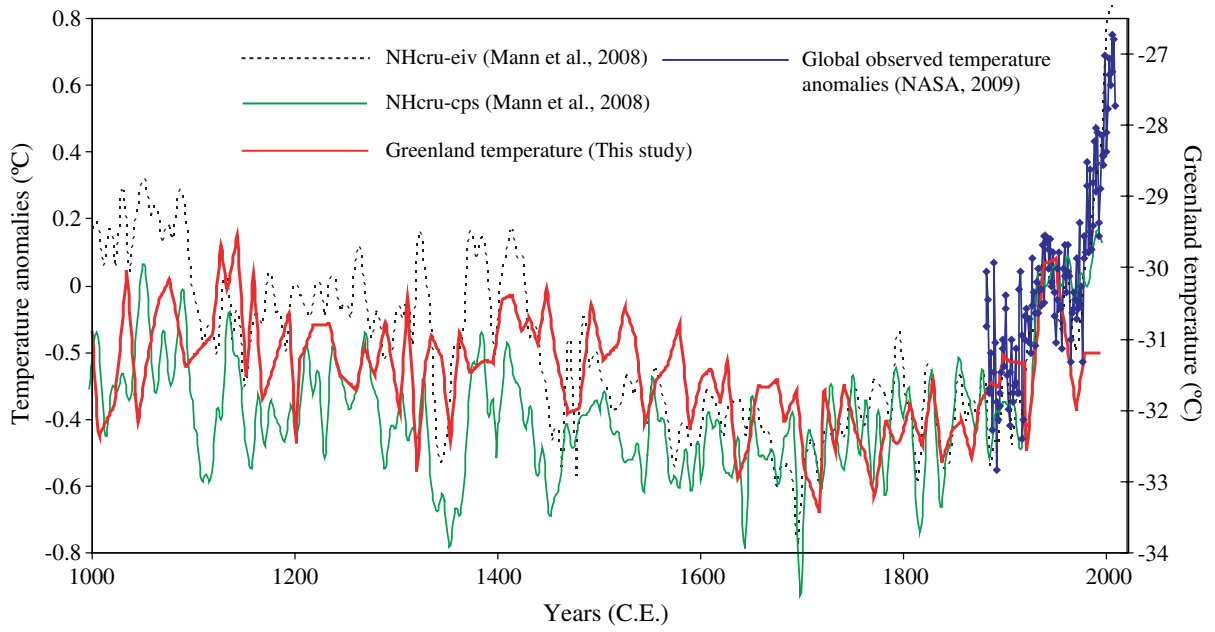

Fig. 17 Reconstructed Greenland temperature (red; this study), global observed temperature anomalies (blue) (NASA 2009), and reconstructed northern hemisphere temperature anomalies (EIV, dotted line; CPS, green) (Mann et al. 2008) for the last 1,000 years 


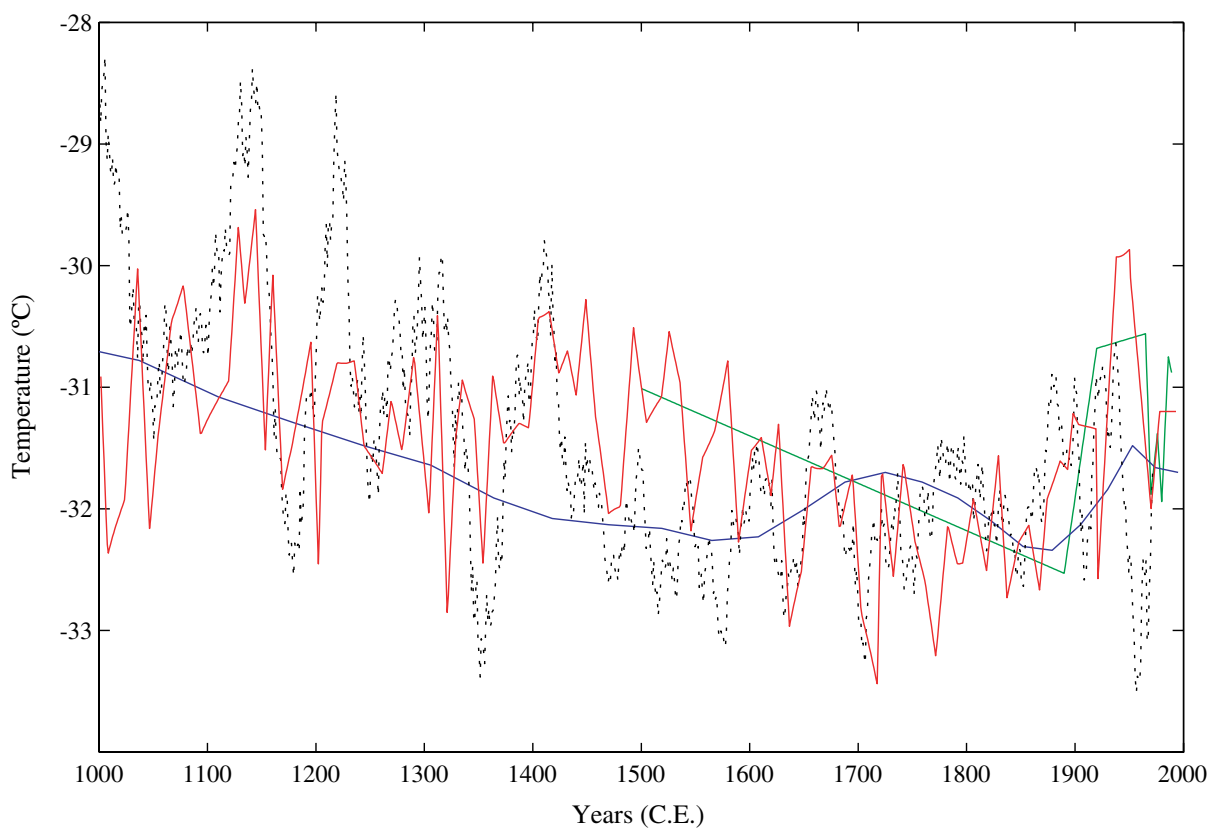

Fig. 18 Greenland temperature reconstructions for the last 1,000 years. Blue line is a reconstruction from borehole temperature using an inverse model for the GRIP site (Dahl-Jensen et al. 1998). Black

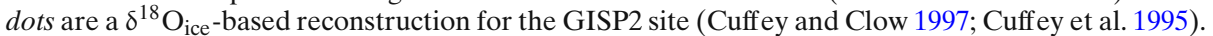
Green line is an heuristic reconstruction using a forward model (Alley and Koci 1990). Red line is the reconstruction from this study

storminess substantially increased as indicated by an increase in Na concentration in the ice (Mayewski et al. 1997). Then, temperature reached its minimum in the eighteenth century. The lengths of alpine glaciers around the globe also reached a maximum around 1800 (Oerlemans 2005). Thereafter, temperature started to increase toward the present. Cooler decades in the warm early millennium are similar to temperatures of warmer decades of the seventeenth to nineteenth centuries, reflecting the severity of the late Little Ice Age.

\section{Multi-decadal temperature fluctuations}

\subsection{Comparison with hemispheric temperature trend}

The reconstructed temperature record shows a quasi-periodic multi-decadal temperature fluctuation (Fig. 19). The spectrum shows three significant peaks with periods of $\sim 330, \sim 70$, and $\sim 40$ years (Fig. 19). Wavelet analyses show 60-70 year multi-decadal fluctuations in the thirteenth century, late eighteenth century to the early nineteenth century (90\% confidence level) (Fig. 20a). Also, decadal temperature variations with shorter period of $\sim 32$ years are significant at the beginning of eleventh century, early seventeenth century, and early twentieth century (Fig. 20a). Although not significant at the $90 \%$ confidence level, shorter decadal variations with periods of 
Fig. 19 Power spectrum of Greenland temperature for the last 1,000 years plotted with red-noise $95 \%$ (dotted) and 99\% (solid) significance levels

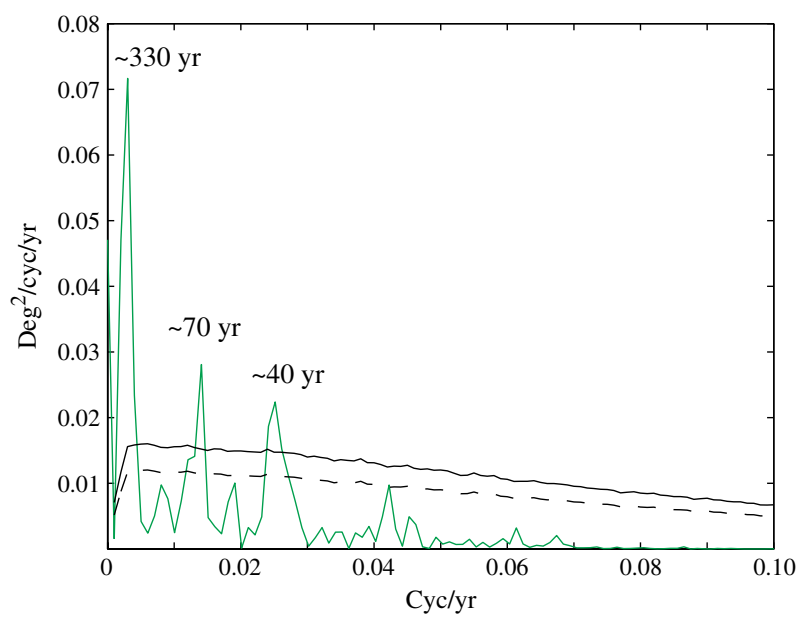

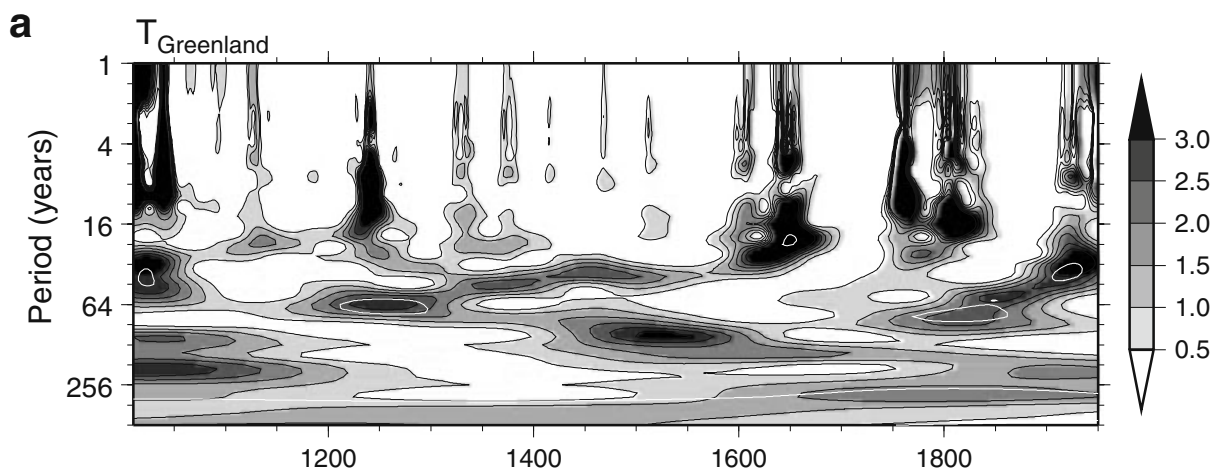

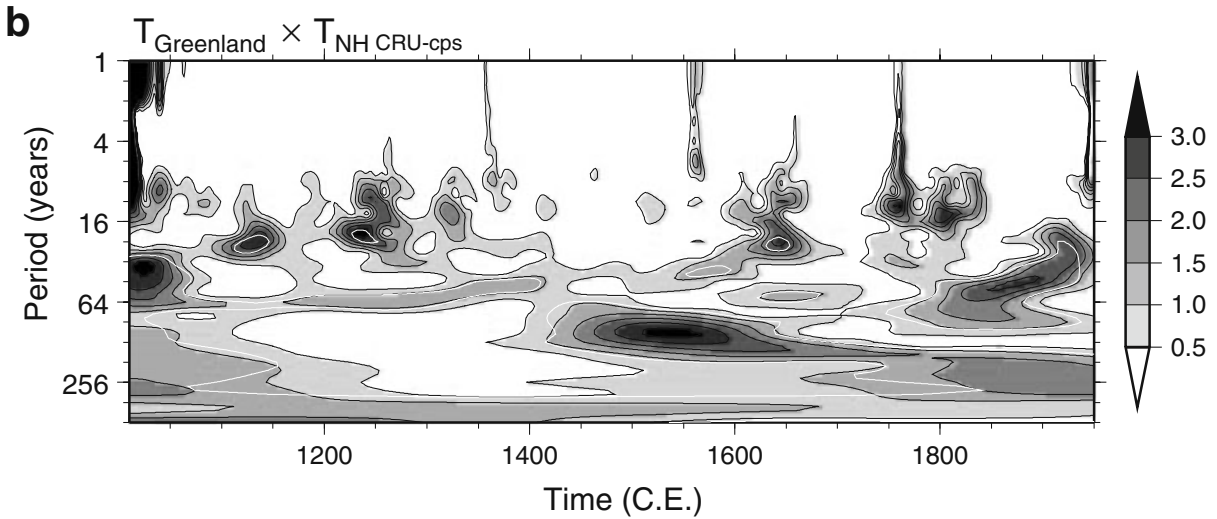

Fig. 20 Results of wavelet (a) and crosswavelet (b) analyses. a Wavelet of the Greenland temperature for the last 1,000 years. b Crosswavelet of reconstructed Greenland temperature and North Hemispheric temperature reconstructions (shown result is with Mann et al. (2008) CPS). Insides of white lines represent a $90 \%$ significance level 
10-20 years appear when the general climatic condition is colder, for example at $\sim 1250$, 1650, 1750-1820, which may imply that a more unstable decadal-scale climate occurs in a cold background climate (Fig. 20a). Fluctuations with periods more than 300 years are also significant (Fig. 20). The multi-decadal periodicity of $\sim 70$-year may relate to the multi-decadal temperature fluctuations in the Atlantic Basin (Atlantic Multidecadal Oscillation: AMO), which is a leading large-scale pattern of multidecadal variability in instrumental records of global temperature (Knight et al. 2005; Schlesinger and Ramankutty 1994).

\subsection{Comparison with other ice core proxies}

The coldest decades of the last millennium around 1700 (Fig. 16) are known as the climax of the Little Ice Age or "Late Maunder Minimum (1675-1715 LMM)" in Europe (Grove 2004; Luterbacher et al. 2001). The close agreement between our temperature record and the composite $\delta^{18} \mathrm{O}_{\text {ice }}$ record from GRIP, DYE-3, and NGRIP (Andersen et al. 2006) (Fig. 13) suggests that the $\delta^{18} \mathrm{O}_{\text {ice }}$ proxy records and temperature change synchronously at a multi-decadal scale, although the multicentennial $\delta^{18} \mathrm{O}_{\text {ice }}$ trends are clearly subdued, likely by factors other than local temperature. The GISP $2 \delta^{18} \mathrm{O}_{\text {ice }}$ record also shows good agreement but to a lesser degree than the composite record. The GISP2 accumulation rate history also seems to be mostly in phase with the multi-decadal temperature fluctuations (Fig. 13).

\section{Climate and people during the last 1,000 years}

The people who lived in climatically marginal Greenland and Iceland received the hardest hits from climatic changes during the last millennium, as recorded in climatically relevant documentation, such as annals and diaries (Ogilvie 1984; Ogilvie and Jonsson 2001). These records provide critical insights on the relationship between climate and people. In addition, Grove (2004) noted that weather in four periods, the fourteenth, late sixteenth, late seventeenth, and eighteenth centuries, was so severe in Europe that it created many events of crop failures often resulting in famines and subsequent widespread social disruptions. These periods also appear to be the most variable and coldest in our data (Fig. 16).

Likewise, medieval texts recounting the Norse colonization of Iceland suggest that the temperature was warmer during the late ninth and early tenth century perhaps similar to the temperature in the early twentieth century (Ogilvie and Jonsson 2001), in agreement with our record. This warming trend, however, was promptly followed by a cooling episode that began as early as 1180 , with reoccurring episodes throughout the twelfth and thirteenth century (Ogilvie 1984; Ogilvie and Jonsson 2001). The fourteenth century was likewise characterized by even more dramatic fluctuations in climatic trends (Ogilvie and Jonsson 2001). Some textural evidence suggest that climate from 1430 to 1560 was milder, with fewer reports of drift ice, severe winters, and poor harvests. The end of the sixteenth century was relatively harsh, continuing into the 1630s, a particularly cold decade, until 1640 (Ogilvie and Jonsson 2001) when temperatures swung back into warmer averages, lasting until 1680 (Ogilvie and Jonsson 2001). The late seventeenth century witnessed one of the coldest periods of the last millennium. The early 1700 s was relatively mild, but by 
the 1740 s and into 1750 s the average temperature was quite low. The 1760 s to 1770 s once again saw a return to milder climate (Ogilvie and Jonsson 2001), only to be followed by the 1780 s, the coldest decade in the eighteenth century (Ogilvie and Jonsson 2001). Perhaps not surprisingly, the Icelandic glaciers reached their Little Ice Age maxima during the eighteenth century (Grove 2004). The 1810s, 1830s, 1860s, and 1880 s were comparatively cold, but the middle nineteenth century was relatively mild (Ogilvie and Jonsson 2001). Although some of the descriptions are beyond our uncertainty, the general trends from historical documents agree with our data quite well (Fig. 16).

\section{Northern hemispheric and Greenland temperatures}

As the reconstructed Greenland temperature correlates well with Northern Hemispheric temperature (Hegerl et al. 2006; Mann et al. 2008; Moberg et al. 2005) (Figs. 13 and 17), it may be inferred that similar mechanisms caused centennial to decadal temperature variation in the central Greenland temperature for the last 1,000 years. The linear correlation coefficients between Greenland temperature and northern hemisphere temperature with data sampled in a 10-year interval are $r=$ 0.35, 0.39, and 0.44 (0.33) for the Moberg (Moberg et al. 2005), Hegerl (Hegerl et al. 2006), and Mann-EIV (CPS) (Mann et al. 2008) reconstructions, respectively (Table 1), where the significance level is more than $98 \%$. Moreover, the nonparametric rank correlation coefficients between the Greenland temperature and Northern Hemispheric temperature are also statistically significant at more than $95 \%$ level. Crosswavelet analyses between reconstructed Greenland temperature and North Hemispheric temperature variations show coherence at periods of $\sim 20$-year around the twelfth, thirteenth, and sixteenth century at the $90 \%$ significance level (Fig. 20b). Also, significant coherences in multi-decadal (40-100 years) fluctuations are found in most times (Fig. 20b). After 1400, significant coherences in long periods of more than 100 years appear (Fig. 20b). From these observations, it can be concluded that northern hemisphere temperature and Greenland temperature for the last 1,000 years synchronously changed in decadal fluctuations at periods of $\sim 20$ years, and especially of 40-100 years. The result for periods of 40-100 years is also fundamentally consistent with other different northern hemisphere temperature reconstructions (Hegerl et al. 2007; Mann et al. 2008; Moberg et al. 2005), suggesting that the multi-decadal synchronous changes are robust results.

The polar climate is known to amplify a global or hemispheric temperature signal by ice albedo feedback (IPCC 2001). General Circulation Models (GCMs)

Table 1 Correlation coefficients between Greenland temperature reconstruction (this study) and northern hemisphere temperature reconstructions, Moberg et al. (2005), Hegerl et al. (2007), Mann et al. (2008)

\begin{tabular}{lllll}
\hline & Moberg & Hegerl & Mann (EIV) & Mann (CPS) \\
\hline Correlation coefficient & 0.35 & 0.39 & 0.44 & 0.33 \\
$\begin{array}{l}\text { Non-parametric rank correlation } \\
\quad 0.25\end{array}$ & 0.25 & 0.29 & 0.18 \\
coefficient (Kendall's $\tau$ ) & & & & \\
\hline
\end{tabular}

To remove the influence of autocorrelation, the correlation coefficients are calculated with data sampled with a 10-year interval. Mann-Kendall tests (two-sided) are all at more than the $95 \%$ significance level 
find that warming of polar regions will progress at a rate 1.2 to 3 times faster than the global average (IPCC 2001). Using our data, the ratio of Greenland to Northern Hemisphere temperature change for the last 1,000 years is 2.3 with the Hegerl reconstruction, 1.4 with the Moberg reconstruction, and 1.5 with the Mann reconstructions. These ratios are comparable to the GCM results (IPCC 2001) and the ratio of 2.2 found from instrumental records (Chylek and Lohmann 2005). This confirms that despite the recent departure in Northern Hemisphere and Greenland temperature trends, the future Greenland temperature will likely follow the global temperature trend with an amplified magnitude.

Changes in solar irradiance and volcanism can explain as much as 41 to $64 \%$ of variation of Northern Hemispheric temperature (Crowley 2000). The strong correlation between Greenland and Northern Hemisphere temperature suggests a common causation. Energy balance model results with solar and volcanic forcing produce the general trend we see in the Greenland temperature record, including the cool eleventh, thirteenth, and fourteenth centuries, the warm twelfth, fourteenth, and twentieth centuries, and the cold seventeenth and nineteenth centuries. Therefore, it is clear that current and future climate change in Greenland is going to be affected by these natural variations in addition to increasing human-made greenhouse gases (Crowley 2000; IPCC 2001). Projections of future Greenland temperature thus must take these natural variations into account.

\section{Conclusions}

We present a new Greenland temperature record for the past 1,000 years based upon argon and nitrogen isotopes in trapped air in ice. The data show clear evidence of the Medieval Warm Period and Little Ice Age in agreement with documentary evidence. The overall trends are similar to northern hemisphere temperature records. A multi-decadal temperature fluctuation with periods of 40-100 persisted for the last millennium, and so will likely continue into the future.

Acknowledgements We thank T. Crowley for reviewing the manuscripts and providing comments. We thank R. Alley, K. Cuffey, G. Clow, J. Ahn, and C. Shuman for the helpful information. We appreciate the support of R. Beaudette and the staff of the National Ice Core Laboratory (NICL). This work was supported by NSF ATM-9905241.

Open Access This article is distributed under the terms of the Creative Commons Attribution Noncommercial License which permits any noncommercial use, distribution, and reproduction in any medium, provided the original author(s) and source are credited.

\section{References}

Allegre CJ, Staudacher T, Sarda P (1987) Rare-gas systematics-formation of the atmosphere, evolution and structure of the earths mantle. Earth Planet Sci Lett 81:127-150

Alley RB, Koci BR (1990) Recent warming in central Greenland? Ann Glaciol 14:6-8

Alley RB, Mayewski PA, Sowers T, Stuiver M, Taylor KC, Clark PU (1997a) Holocene climatic instability: a prominent, widespread event 8200 yr ago. Geology 25:483-486

Alley RB, Shuman CA, Meese DA, Gow AJ, Taylor KC, Cuffey KM, Fitzpatrick JJ, Grootes PM, Zielinski GA, Ram M, Spinelli G, Elder B (1997b) Visual-stratigraphic dating of the GISP2 ice core: basis, reproducibility, and application. J Geophys Res C Oceans 102:26367-26381 
Andersen KK, Ditlevsen PD, Rasmussen SO, Clausen HB, Vinther BM, Johnsen SJ, Steffensen JP (2006) Retrieving a common accumulation record from Greenland ice cores for the past 1800 years. J Geophys Res-Atmos. doi:10.1029/2005JD006765

Chylek P, Lohmann U (2005) Ratio of the Greenland to global temperature change: comparison of observations and climate modeling results. Geophys Res Lett 32. doi:10.1029/2005GL023552

Clow GD, Saltus RW, Waddington ED (1996) A new high-precision borehole-temperature logging system used at GISP2, Greenland, and Taylor Dome, Antarctica. J Glaciol 42: 576-584

Craig H, Horibe Y, Sowers T (1988) Gravitational separation of gases and isotopes in polar ice caps. Science 242:1675-1678

Crowley TJ (2000) Causes of climate change over the past 1000 years. Science 289:270-277

Crowley TJ, Baum SK, Kim KY, Hegerl GC, Hyde WT (2003) Modeling ocean heat content changes during the last millennium. Geophys Res Lett 30. doi:10.1029/2003GL017801

Cuffey KM, Clow GD (1997) Temperature, accumulation, and ice sheet elevation in central Greenland through the last deglacial transition. J Geophys Res C Oceans 102:26383-26396

Cuffey KM, Clow GD, Alley RB, Stuiver M, Waddington ED, Saltus RW (1995) Large Arctic temperature-change at the Wisconsin-Holocene glacial transition. Science 270:455-458

Dahl-Jensen D, Mosegaard K, Gundestrup N, Clow GD, Johnsen SJ, Hansen AW, Balling N (1998) Past temperatures directly from the Greenland Ice Sheet. Science 282:268-271

Fisher DA, Reeh N, Clausen HB (1985) Stratigraphic noise in time series derived from ice cores. Ann Glaciol 7:76-83

Goujon C, Barnola JM, Ritz C (2003) Modeling the densification of polar firn including heat diffusion: application to close-off characteristics and gas isotopic fractionation for Antarctica and Greenland sites. J Geophys Res-Atmos 108. doi:10.1029/2002JD003319

Grachev AM, Severinghaus JP (2003a) Determining the thermal diffusion factor for Ar-40/Ar-36 in air to aid paleoreconstruction of abrupt climate change. J Phys Chem A 107:4636-4642

Grachev AM, Severinghaus JP (2003b) Laboratory determination of thermal diffusion constants for N-29(2)/N-28(2) in air at temperatures from -60 to 0 degrees $C$ for reconstruction of magnitudes of abrupt climate changes using the ice core fossil-air paleothermometer. Geochim Cosmochim Acta 67:345-360

Grove JM (2001) The initiation of the "Little Ice Age" in regions round the North Atlantic. Clim Change 48:53-82

Grove JM (2004) Little ice ages: ancient and modern. Routledge, London

Hegerl GC, Crowley TJ, Hyde WT, Frame DJ (2006) Climate sensitivity constrained by temperature reconstructions over the past seven centuries. Nature 440:1029-1032

Hegerl GC, Crowley TJ, Allen M, Hyde WT, Pollack HN, Smerdon J, Zorita E (2007) Detection of human influence on a new, validated 1500-year temperature reconstruction. J Climate 20: $650-666$

Huber C, Beyerle U, Leuenberger M, Schwander J, Kipfer R, Spahni R, Severinghaus JP, Weiler K (2006) Evidence for molecular size dependent gas fractionation in firn air derived from noble gases, oxygen, and nitrogen measurements. Earth Planet Sci Lett 243:61-73

IPCC (2001) The scientific basis: contribution of working group I to the third assessment report of the intergovermental panel on climate change. Cambridge University Press, Cambridge

Jones PD, Mann ME (2004) Climate over past millennia. Rev Geophys 42. doi:10.1029/ 2003RG000143

Knight JR, Allan RJ, Folland CK, Vellinga M, Mann ME (2005) A signature of persistent natural thermohaline circulation cycles in observed climate. Geophys Res Lett 32. doi:10.1029/ 2005GL024233

Kobashi T (2007) Greenland temperature, climate change, and human society during the last 11,600 years. Ph.D. thesis, University of California, San Diego

Kobashi T, Severinghaus J, Brook EJ, Barnola JM, Grachev A (2007) Precise timing and characterization of abrupt climate change 8,200 years ago from air trapped in polar ice. Quat Sci Rev 26:1212-1222

Kobashi T, Severinghaus JP, Barnola JM (2008a) $4 \pm 1.5^{\circ} \mathrm{C}$ abrupt warming 11,270 years ago identified from trapped air in Greenland ice. Earth Planet Sci Lett 268:397-407

Kobashi T, Severinghaus JP, Kawamura K (2008b) Argon and nitrogen isotopes of trapped air in the GISP2 ice core during the Holocene epoch (0-11,600 B.P.): methodology and implications for gas loss processes. Geochim Cosmochim Acta 72:4675-4686

Landais A, Barnola JM, Kawamura K, Caillon N, Delmotte M, Van Ommen T, Dreyfus G, Jouzel J, Masson-Delmotte V, Minster B, Freitag J, Leuenberger M, Schwander J, Huber C, Etheridge D, 
Morgan V (2006) Firn-air delta N-15 in modern polar sites and glacial-interglacial ice: a modeldata mismatch during glacial periods in Antarctica? Quat Sci Rev 25:49-62

Li J, Zwally HJ, Cornejo C, Yi DH (2003) Seasonal variation of snow-surface elevation in North Greenland as modeled and detected by satellite radar altimetry. Ann Glaciol 37:233-238

Luterbacher J, Rickli R, Xoplaki E, Tinguely C, Beck C, Pfister C, Wanner H (2001) The Late Maunder Minimum (1675-1715) - a key period for studying decadal scale climatic change in Europe. Clim Change 49:441-462

Mann ME, Zhang Z, Hughes MK, Bradley RS, Miller SK, Rutherford S, Ni F (2008) Proxy-based reconstructions of hemispheric and global surface temperature variations over the past two millennia. Proc Natl Acad Sci U S A 105:13252-13257

Mariotti A (1983) Atmospheric nitrogen is a reliable standard for natural N-15 abundance measurements. Nature 303:685-687

Mayewski PA, Meeker LD, Twickler MS, Whitlow S, Yang QZ, Lyons WB, Prentice M (1997) Major features and forcing of high-latitude northern hemisphere atmospheric circulation using a 110,000-year-long glaciochemical series. J Geophys Res C Oceans 102:26345-26366

Moberg A, Sonechkin DM, Holmgren K, Datsenko NM, Karlen W (2005) Highly variable Northern hemisphere temperatures reconstructed from low- and high-resolution proxy data. Nature 433:613-617

NASA (2009) GISS surface temperature analysis. Available at http://data.giss.nasa.gov/gistemp/

National Research Council (U.S.) Committee on Surface Temperature Reconstructions for the Last 2000 Years (2006) Surface temperature reconstructions for the last 2,000 years. National Academies Press, Washington, $\mathrm{p}$ xiv, 145

Oerlemans J (2005) Extracting a climate signal from 169 glacier records. Science 308:675-677

Ogilvie AEJ (1984) The past climate and sea-ice record from Iceland. 1. Data to Ad 1780. Clim Change 6:131-152

Ogilvie AEJ, Jonsson T (2001) "Little Ice Age" research: a perspective from Iceland. Clim Change 48:9-52

Schlesinger ME, Ramankutty N (1994) An oscillation in the global climate system of period 65-70 years. Nature 367:723-726

Schwander J, Sowers T, Barnola JM, Blunier T, Fuchs A, Malaize B (1997) Age scale of the air in the summit ice: implication for glacial-interglacial temperature change. J Geophys Res-Atmos 102:19483-19493

Severinghaus JP, Battle MO (2006) Fractionation of gases in polar lee during bubble close-off: new constraints from firn air Ne, Kr and Xe observations. Earth Planet Sci Lett 244:474-500

Severinghaus JP, Brook EJ (1999) Abrupt climate change at the end of the last glacial period inferred from trapped air in polar ice. Science 286:930-934

Severinghaus JP, Sowers T, Brook EJ, Alley RB, Bender ML (1998) Timing of abrupt climate change at the end of the Younger Dryas interval from thermally fractionated gases in polar ice. Nature 391:141-146

Severinghaus JP, Grachev A, Luz B, Caillon N (2003) A method for precise measurement of argon 40/36 and krypton/argon ratios in trapped air in polar ice with applications to past firn thickness and abrupt climate change in Greenland and at Siple Dome, Antarctica. Geochim Cosmochim Acta 67:325-343

Stuiver M, Grootes PM, Braziunas TF (1995) The GISP2 delta O-18 climate record of the past 16,500 years and the role of the sun, ocean, and volcanoes. Quat Res 44:341-354

Vinther BM, Andersen KK, Jones PD, Briffa KR, Cappelen J (2006) Extending Greenland temperature records into the late eighteenth century. J Geophys Res 111. doi:10.1029/2005JD006810

Zwally HJ, Jun L (2002) Seasonal and interannual variations of firn densification and ice-sheet surface elevation at the Greenland summit. J Glaciol 48:199-207 